\title{
Evaluation of damage to main crops caused by the most important agrophages in Poland in 2013
}

\section{Ocena uszkodzeń spowodowanych przez najważniejsze agrofagi głównych roślin uprawnych w Polsce w roku 2013}

\author{
Felicyta Walczak ${ }^{1}$, Andrzej Bandyk ${ }^{1}$, Magdalena Jakubowska ${ }^{1}$, Kamila Roik $^{1}$, Anna Tratwal $^{1}$, \\ Beata Wielkopolan ${ }^{1}$, Jan Złotkowski ${ }^{1}$, Inspektorzy Wojewódzkich Inspektoratów PIORiN ${ }^{2}$
}

\section{Summary}

The paper presents harmfulness estimation of the most important diseases and pests occurring in main agricultural and horticultural crops in Poland in 2013. Presented data are based on the results of field observations provided by the Plant Health and Seed Inspection Service Inspectors. In 2013 the increase of agrophages' occurrence was recorded for the following species: Blumeria graminis (DC.) Speer, Puccinia recondita Rob. ex Desm. f. sp. tritici (Erikss.) C.O. Johnson, Fusarium spp., Molisia yallundae Wollwork et Spooner, Gaeumannomyces graminis (Sacc.) Arx et Olivier - on wheat, Fusarium spp. - on maize, Leptinotarsa decemlineata Say - on potato, Leptosphaeria spp. - on winter rape, Pseudoperonospora cubensis (Berk. et Curt.) Rostovzev, Pseudomonas syringae pv. lachrymans (Sm. et B.) Young, Brevicoryne brassicae L., Chamaepsila rosae Fabr. - on vegetable crops, Monilinia laxa (Aderh. et Ruhl.) Honey, Hoplocampa spp., Cydia funebrana Tr., Botrytinia fuckeliana (De Bary) Whetzel. - in orchards comparing to 2012.

Key words: pests; diseases; harmfulness; evaluation

\section{Streszczenie}

W pracy przedstawiono ocenę szkód spowodowanych przez najważniejsze choroby i szkodniki głównych roślin uprawnych w Polsce w roku 2013. Prezentowane dane oparte są na wynikach obserwacji terenowych, dostarczonych przez Państwową Inspekcję Ochrony Roślin i Nasiennictwa. W roku 2013 zwiększenie nasilenia występowania agrofagów w porównaniu z wynikami uzyskanymi w roku 2012 stwierdzono w przypadku: Blumeria graminis (DC.) Speer, Puccinia recondita Rob. ex Desm. f. sp. tritici (Erikss.) C.O. Johnson, Fusarium spp., Molisia yallundae Wollwork et Spooner, Gaeumannomyces graminis (Sacc.) Arx et Olivier: - na pszenicy, Fusarium spp. - na kukurydzy, Leptinotarsa decemlineata Say - na ziemniaku, Leptosphaeria spp. - na rzepaku ozimym, Pseudoperonospora cubensis (Berk. et Curt.) Rostovzev, Pseudomonas syringae pv. lachrymans (Sm. et B.) Young, Brevicoryne brassicae L., Chamaepsila rosae Fabr. - na warzywach oraz Monilinia laxa (Aderh. et Ruhl.) Honey, Hoplocampa spp., Cydia funebrana Tr., Botrytinia fuckeliana (De Bary) Whetzel. - w sadach.

Słowa kluczowe: szkodniki; choroby; szkodliwość; ocena

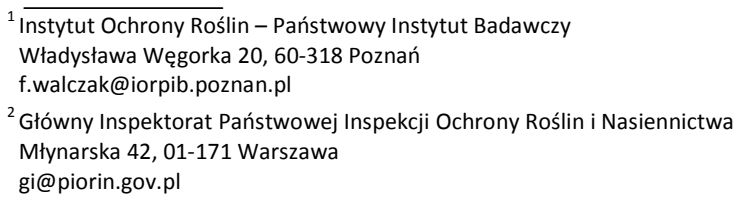




\section{Wstęp / Introduction}

Celem badań jest ocena zdrowotności wybranych roślin uprawnych w Polsce w 2013 roku na podstawie wyników corocznego, ogólnokrajowego monitorowania wybranych agrofagów, przekazywanych z Państwowej Inspekcji Ochrony Roślin i Nasiennictwa (PIORiN) do Zakładu Metod Prognozowania Agrofagów i Ekonomiki Ochrony Roślin Instytutu Ochrony Roślin - Państwowego Instytutu Badawczego (IOR - PIB) w Poznaniu. Uwzględniono: rośliny zbożowe (pszenica, kukurydza), okopowe (ziemniak, burak cukrowy), przemysłowe (rzepak), warzywne (pomidor, ogórek, cebula, kapusta, marchew) i sadownicze (jabłoń, śliwa, czereśnia, wiśnia i truskawka). W roku 2013 zwiększenie nasilenia występowania agrofagów, w porównaniu z wynikami uzyskanymi w roku 2012, stwierdzono w przypadku: Blumeria graminis (DC.) Speer, Puccinia recondita Rob. ex Desm. f. sp. tritici (Erikss.) C.O. Johnson, Fusarium spp., Molisia yallundae Wollwork et Spooner, Gaeumannomyces graminis (Sacc.) Arx et Olivier: - na pszenicy, Fusarium spp. - na kukurydzy, Leptinotarsa decemlineata Say - na ziemniaku, Leptosphaeria spp. - na rzepaku ozimym, Pseudoperonospora cubensis (Berk. et Curt.) Rostovzev, Pseudomonas syringae pv. lachrymans (Sm. et B.) Young, Brevicoryne brassicae L., Chamaepsila rosae Fabr. - na warzywach oraz Monilinia laxa (Aderh. et Ruhl.) Honey, Hoplocampa spp., Cydia funebrana Tr., Botrytinia fuckeliana (De Bary) Whetzel. w sadach.

\section{Materiały i metody / Materials and methods}

Wszystkie obserwacje dotyczące ogólnokrajowego monitorowania oceny uszkodzeń spowodowanych przez agrofagi zostały wykonane według metodyk zawartych w instrukcjach dla służby ochrony roślin z zakresu prognoz, sygnalizacji i rejestracji (Instrukcja 1976, 1982, 1993) oraz aneksach do instrukcji (Aneksy 1998) i poradnikach (Poradnik 2007, 2008), opracowanych w IOR - PIB w Poznaniu. Ocena szkodliwości polega na jednorazowym przeprowadzeniu obserwacji w sezonie wegetacyjnym w ściśle dla danego agrofaga określonym terminie. Wyniki obserwacji przeprowadzonych przez pracowników PIORiN w roku 2013 zostały przekazane w formie raportów z oddziałów terenowych. Po przetworzeniu ich w Zakładzie Metod Prognozowania Agrofagów i Ekonomiki Ochrony Roślin IOR - PIB uzyskano wartości średnie uszkodzeń spowodowanych przez agrofagi dla wojewódzkich inspektoratów, wyrażone procentem porażonych lub uszkodzonych liści, roślin, źdźbeł, łuszczyn, owoców itp., w zależności od rodzaju uszkodzeń, jakie wyrządza określony agrofag. Lista agrofagów corocznie aktualizowana jest przez PIORiN. Ocena uszkodzeń spowodowanych przez agrofagi jest niezależna od stopnia ochrony roślin. Wyniki z roku 2013 porównano do średnich krajowych uzyskanych w roku poprzednim (Walczak i wsp. 2013), a w przypadkach szczególnych do średnich krajowych na przestrzeni kilku minionych lat oraz średnich wieloletnich z okresu 1991-2013 (Walczak i wsp. 2014).
Do badań w sposób celowy wybrano 13 gatunków roślin z czego 38,5\% stanowiły rośliny rolnicze, tyle samo warzywnicze i 23,0\% sadownicze. Dokładnej analizie poddano 42 agrofagi. W opracowaniu przedstawiono zmiany dotyczące rejonizacji i nasilenia szkód spowodowanych przez gospodarczo ważne choroby i szkodniki roślin uprawnych w roku 2013 oraz porównano je z wynikami obserwacji przeprowadzonymi analogicznie w roku 2012 (Walczak i wsp. 2013) i średnimi wieloletnimi dla Polski z lat 1991-2013. Ponadto w przypadkach szczególnych porównano do średnich krajowych $\mathrm{z}$ kilku lub kilkunastu minionych lat.

\section{Wyniki i dyskusja / Results and discussion}

\section{Choroby i szkodniki roślin zbożowych Diseases and pests of cereals}

\section{Z boża - Cereals}

\section{Mączniak prawdziwy zbóż - Blumeria graminis DC.}

Mączniak prawdziwy w roku 2013 obserwowano na terenie całego kraju. Średnio dla Polski odnotowano 15,4\% porażonych źdźbeł pszenicy ozimej (w roku 2012 $14,5 \%)$. Średni w skali kraju procent porażonych źdźbeł od roku 2002 utrzymuje się poniżej wartości średniej wieloletniej, która wynosi 23,2\%.

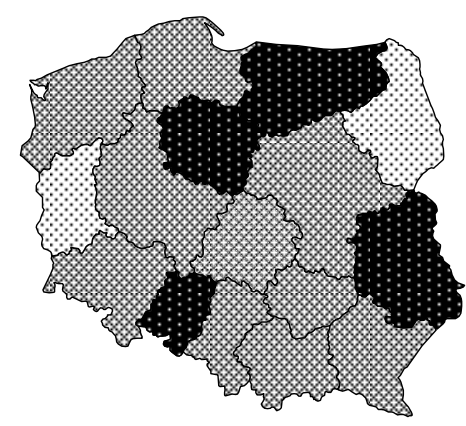

Rys. 1. Mączniak prawdziwy zbóż B. graminis DC

$\%$ porażonych źdźbeł pszenicy ozime $\%$ infected stems of winter wheat

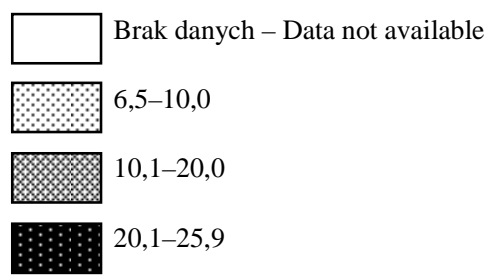

Największe nasilenie mączniaka prawdziwego, na poziomie ponad $20 \%$ porażonych źdźbeł pszenicy ozimej, obserwowano w województwach: opolskim - średnio $25,9 \%$, lokalnie w oddziałach terenowych $83,0 \%$ (Strzelce Opolskie), 60,0\% (Nysa), 39,0-48,0\% (Kluczbork, Prudnik i Głubczyce); kujawsko-pomorskim - średnio 24,1\%, lokalnie 100,0\% (Świecie i Tuchola), 60,0\% (Radziejów), 
22,0-28,0\% (Żnin, Bydgoszcz, Chełmno); warmińsko-mazurskim - średnio 23,5\%, lokalnie 100\% (Braniewo), 62,0-70,0\% (Węgorzewo i Giżycko) oraz lubelskim średnio 20,3\%, lokalnie 100,0\% (Lublin), 80,0-90,0\% (Tomaszów Lubelski i Zamość). Większe nasilenie obserwowano ponadto w województwach: dolnośląskim średnio $18,9 \%$ porażonych źdźbeł, lokalnie w oddziałach terenowych 100,0\% (Wałbrzych), 65,0\% (Jelenia Góra), 30,0-40,0\% (Oleśnica, Strzelin, Środa Śląska, Ząbkowice Śląskie, Trzebnica, Góra); łódzkim - średnio 17,4\%, lokalnie 50,0\% (Tomaszów Mazowiecki), 30,0\% (Piotrków Trybunalski), 20,0-21,0\% (Łask, Brzeziny, Łęczyca); mazowieckim - średnio 14,4\%, lokalnie 70,0-100,0\% (Mława, Ostrów Mazowiecki, Siedlce, Sokołów Podlaski) oraz podkarpackim - średnio 14,4\%, lokalnie 100,0\% (Mielec), 50,0\% (Przemyśl), 35,0\% (Przeworsk) i 25,0\% (Jasło).

Najniższe porażenie odnotowano w województwie podlaskim - 6,5\% źdźbeł pszenicy ozimej.

\section{Rdza brunatna pszenicy - Puccinia recondita Rob. ex Desm.} f. sp. tritici (Erikss.) C.O. Johnson

Występowanie choroby obserwowano powszechnie na terenie całego kraju, odnotowując średnio $10,3 \%$ porażonych źdźbeł pszenicy ozimej. Stwierdzono wzrost nasilenia występowania choroby w porównaniu do odnotowanego w roku $2012(8,5 \%)$, a średni w skali kraju procent porażonych źdźbeł utrzymuje się poniżej wartości średniej wieloletniej $(10,8 \%)$.

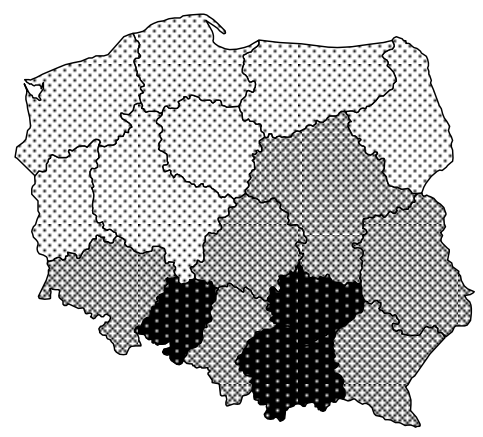

Rys. 2. Rdza brunatna pszenicy $P$. recondita Rob. ex Desm. f. sp. tritici (Erikss.) C.O. Johnson

$\%$ porażonych źdźbeł pszenicy ozimej

$\%$ infected stems of winter wheat

$\square$ Brak danych - Data not available
$1,1-7,0$
$7,1-17,0$
$17,1-34,0$

Zgodnie z przewidywaniami największe nasilenie rdzy brunatnej pszenicy (podobnie, jak w latach ubiegłych), stwierdzono głównie w województwach południowo- -wschodnich i południowych. Większe nasilenie występowania rdzy brunatnej pszenicy, przekraczające średnią krajową, odnotowano w województwach: świętokrzyskim - 34,0\% porażonych źdźbeł pszenicy ozimej (w roku 2012 - 6,7\%), lokalnie w oddziałach terenowych 100,0\% (Jędrzejów) i 90,0\% (Staszów); małopolskim - 18,9\% (w roku $2011-15,1 \%$ ), lokalnie 100,0\% (Bochnia); lubelskim - 16,1\% (w roku $2011-15,2 \%$ ), lokalnie 92,0\% (Zamość), 68,0\% (Włodawa), 50,0\% (Puławy), 28,0\% (Biała Podlaska), 20,0\% (Lublin, Opole Lubelskie, Tomaszów Lubelski i Hrubieszów) oraz podkarpackim $10,5 \%$ (w roku $2011-11,0 \%$ ), lokalnie 68,0\% (Leżajsk), $40,0 \%$ (Jasło) i 20,0-22,0\% (Lubaczów i Mielec).

Najniższe porażenie odnotowano w województwach podlaskim - 1,1\% źdźbeł pszenicy ozimej i zachodniopomorskim $-1,8 \%$.

\section{Septorioza plew pszenicy - Phaeosphaeria nodorum (Müller) Hedjaroude}

W roku 2013 septoriozę plew pszenicy ozimej rejestrowano powszechnie na terenie kraju (średnio $9,0 \%$ porażonych kłosów pszenicy ozimej) w nasileniu niższym niż w roku $2012(10,1 \%)$. Średni dla Polski procent porażonych kłosów pszenicy ozimej przez septoriozę plew od roku 2002 kształtuje się poniżej poziomu średniej wieloletniej, która wynosi $12,8 \%$.
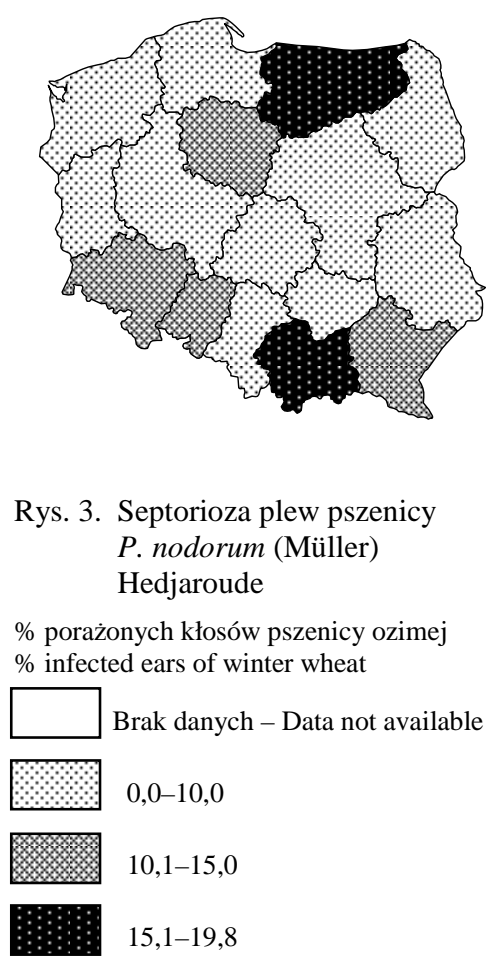

Zgodnie $\mathrm{z}$ oceną, największe nasilenie występowania choroby, przekraczające średnią krajową odnotowano w rejonach Polski północno-wschodniej i południowo-wschodniej, tj.: małopolskim, gdzie średnio stwierdzono 19,8\% porażonych kłosów pszenicy ozimej (w roku 2012 $15,3 \%$ ), lokalnie w oddziałach terenowych $100 \%$ (Bochnia i Nowy Sącz), 50,0-60,0\% (Zakopane i Sucha Beskidzka); 
warmińsko-mazurskim - 15,6\% (w roku $2012-22,7 \%)$, lokalnie $56,0 \%$ (Giżycko), 40,0-44,0\% (Węgorzewo i Ełk), opolskim - 14,3\% (w roku $2012-4,7 \%$ ), lokalnie $85,5 \%$ (Strzelce Opolskie), 31,0-40,0\% (Brzeg, Głubczyce, Nysa); podkarpackim - 12,5\% (w roku 2012 13,6\%), lokalnie 75,0\% (Strzyżów), 30,0\% (Lubaczów), $25,0 \%$ (Leżajsk); dolnośląskim - 12,1\% (w roku 2012 12,6\%), lokalnie 70,0-80,0\% (Jelenia Góra i Lubań), 20,0$36,0 \%$ (Oława, Oleśnica, Strzelin, Środa Śląska); kujawsko-pomorskim - 11,3\% (w roku 2012 - 18,0\%), lokalnie 100,0\% (Brodnica), 23,0-24,0\% (Tuchola i Świecie) oraz świętokrzyskim - 9,3\% (w roku $2012-14,0 \%$ ), lokalnie 25,0\% (Jędrzejów).

Najniższe porażenie źdźbeł pszenicy ozimej przez septoriozę plew, około $3,0 \%$, odnotowano w województwach łódzkim i lubuskim.

\section{Fuzariozy kłosów zbóż - Fusarium spp.}

Rok 2013 był kolejnym, szóstym rokiem, w którym występowanie grzybów rodzaju Fusarium, powodujących fuzariozy kłosów, zostało objęte rejestracją szczegółową. Porażenie kłosów pszenicy ozimej przez Fusarium spp. notowano na terenie kraju powszechnie (poza województwem świętokrzyskim), ale w małym nasileniu. W porównaniu do wyników obserwacji przeprowadzonych w roku 2012 stwierdzono większe nasilenie występowania fuzarioz na kłosach pszenicy ozimej i odnotowano średnio w skali kraju 4,6\% porażonych kłosów (w roku 2012 $3,8 \%)$.

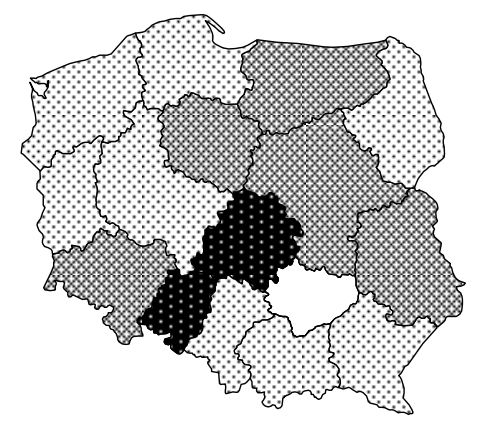

Rys. 4. Fuzariozy kłosów zbóż Fusarium spp.

\% porażonych kłosów pszenicy ozimej

$\%$ infected ears of winter wheat

\begin{tabular}{ll}
\hline & Brak danych - Data not available \\
\hline 1 & $1,6-4,0$ \\
10 & $4,1-10,0$ \\
$10,1-11,0$
\end{tabular}

Nasilenie powyżej średniej krajowej rejestrowano w województwach: łódzkim - 11,0\% porażonych kłosów pszenicy ozimej (w roku 2012 - 3,0\%), lokalnie w oddziale terenowym 19,0\% (Piotrków Trybunalski); opolskim $-10,2 \%$ (w roku $2012-3,0 \%$ ), lokalnie 27,0-41,0\% (Brzeg i Strzelce Opolskie); warmińsko-mazurskim - 7,3\% (w roku 2012 - 11,8\%), lokalnie 42,0\% (Węgorzewo) i 23,0\% (Giżycko) oraz dolnośląskim - 5,2\% (w roku 2012 - 6,6\%), lokalnie 30,0-50,0\% (Dzierżoniów i Lubań), 10,0-25,0\% (Wrocław, Wołów, Oleśnica, Lwówek Śląski, Strzelin, Środa Śląska i Oława).

Najmniej porażonych kłosów pszenicy ozimej przez grzyby rodzaju Fusarium odnotowano w województwie zachodniopomorskim - 1,6\%.

\section{Łamliwość źdźbła zbóż - Molisia yallundae Wollwork et Spooner}

W roku 2013 łamliwość podstawy źdźbła, podobnie jak w latach ubiegłych, występowała na terenie kraju powszechnie, ale w małym nasileniu. Średnio dla kraju odnotowano $3,6 \%$ porażonych źdźbeł pszenicy ozimej ('średnia z wielolecia - 5,0\%).

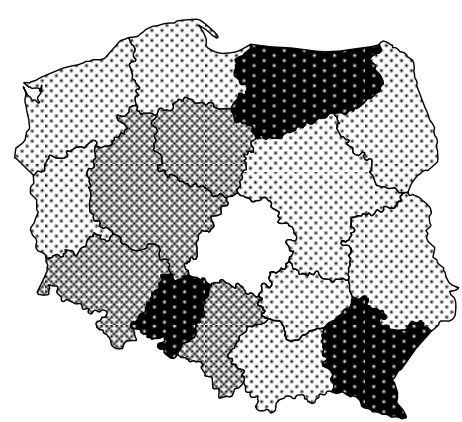

Rys. 5. Łamliwość źdźbła zbóż M. yallundae Wollwork et Spooner

$\%$ porażonych źdźbeł pszenicy ozimej $\%$ infected stems of winter wheat

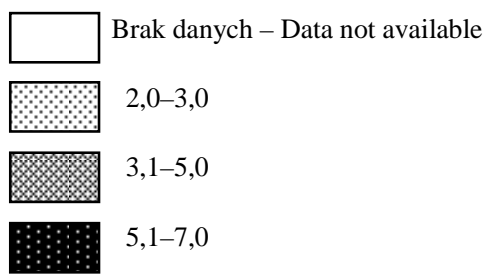

Większe nasilenie choroby, powyżej średniej krajowej, odnotowano głównie w województwach: warmińskomazurskim - średnio 7,0\% porażonych źdźbeł pszenicy ozimej (w roku 2012 - 4,5\%), lokalnie w oddziale terenowym 55,0\% (Giżycko); opolskim - średnio 6,4\% (w roku 2012 - 5,4\%), lokalnie 26,0\% (Brzeg); podkarpackim - średnio 5,4\% (w roku 2012 - 5,3\%), lokalnie 40,0\% (Lubaczów), 24,0-25,0\% (Kolbuszowa i Strzyżów); kujawsko-pomorskim - średnio 4,1\% (w roku 2012 2,4\%), lokalnie 10,0-12,0\% (Tuchola, Włocławek, Toruń); dolnośląskim - średnio 3,8\% (w roku 2012 - 4,5\%), lokalnie 20,0\% (Strzelin), 10,0\% (Lubin, Jawor, Legnica, Oleśnica) oraz śląskim i wielkopolskim - średnio 3,7\% (w roku 2012 - 3,5 i 3,0\%), lokalnie 30,0\% (Oborniki).

\section{Zgorzel podstawy źdźbła - Gaeumannomyces graminis (Sacc.) Arx et Olivier}

W roku 2013 informacje o występowaniu zgorzeli podstawy źdźbła nadesłano z 14 województw (oprócz woje- 
wództwa dolnośląskiego i warmińsko-mazurskiego). Średnio dla Polski, odnotowano 3,0\% porażonych roślin pszenicy ozimej (w roku 2012 - 2,6\%). Od roku 2002 porażenie pszenicy ozimej przez zgorzel podstawy źdźbła kształtuje się poniżej wartości średniej wieloletniej (4,2\%).

Większe nasilenie choroby $\mathrm{w}$ roku 2013, powyżej średniej krajowej, odnotowano w województwach: śląskim - gdzie porażonych zostało średnio 6,0\% roślin pszenicy ozimej, lokalnie w oddziale terenowym 10,0\% (Kłobuck); kujawsko-pomorskim i małopolskim - średnio 3,6\%, lokalnie 12,0\% (Włocławek i Toruń - kujawsko-pomorskie) oraz 10,0-22,0\% (Nowy Sacz i Limanowa - małopolskie); wielkopolskim - średnio 3,2\%, lokalnie $15,0 \%$ (Oborniki) oraz podkarpackim - średnio 3,1\%, lokalnie $22,0 \%$ (Mielec).

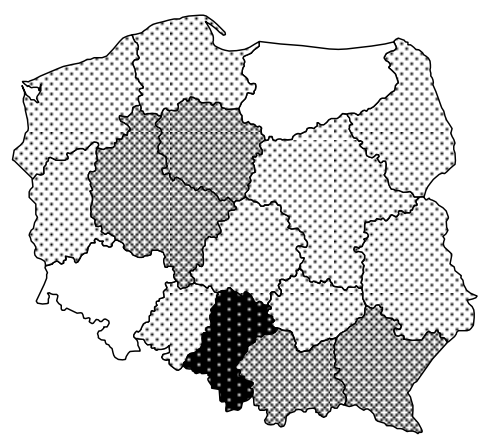

Rys. 6. Zgorzel podstawy źdzbła G. graminis (Sacc.) Arx et Olivier var. tritici Walker $\%$ porażonych roślin pszenicy ozimej $\%$ infected winter wheat plants

\begin{tabular}{|l}
\hline \\
\hline \\
$2,1-3,0$ \\
$3,1-5,0$ \\
$5,1-6,0$
\end{tabular}

Najmniejsze nasilenie choroby notowano w województwie świętokrzyskim - 2,0\% porażonych roślin pszenicy ozimej.

\section{Skrzypionki - Oulema spp.}

Występowanie skrzypionek na pszenicy ozimej w roku 2013 obserwowano na terenie całego kraju. Chrząszcze i larwy uszkodziły średnio 7,1\% źdźbeł (w roku 2012 $7,8 \%$ ), co kształtowało się poniżej wartości średniej krajowej z ostatnich 22 lat (9,0\%). Od roku 2006 średni w skali kraju poziom szkodliwości mieści się w przedziale 7,0-7,8\% uszkodzonych źdźbeł pszenicy ozimej.

Pomimo zmniejszenia się w skali kraju poziomu szkodliwości w niektórych województwach stwierdzono średnio większą liczbę uszkodzonych źdźbeł pszenicy ozimej w porównaniu do odnotowanej w roku 2012. Do takich województw należały: opolskie (z 6,2 do 9,0\%), święto- krzyskie (z 5,6 do 8,0\%), mazowieckie (z 5,0 do 6,7\%), podlaskie (z 3,7 do 4,9\%), a o mniej niż $1 \%$ w województwach: zachodniopomorskim, lubelskim i pomorskim.

W skali województw uszkodzenie źdźbeł powyżej wartości średniej krajowej $(7,1 \%)$ odnotowano w: warmińsko-mazurskim - średnio $11,0 \%$, a lokalnie w oddziałach terenowych 17,0\% (Braniewo), 25,0-30,0\% (Ełk, Nowe Miasto Lubawskie, Elbląg); w wymienionym już opolskim - średnio 9,0\%, lokalnie 10,0-15,0\% (Namysłów, Głubczyce, Prudnik, Nysa), 20,0-22,0\% (Brzeg, Opole, Kluczbork); świętokrzyskim - średnio 8,0\%, lokalnie 15,0-20,0\% (Jędrzejów, Staszów); śląskim - średnio 8,5\%, lokalnie 30,0\% (Kłobuck), 40,0\% (Pszczyna, Katowice), 95,0\% (Gliwice); kujawsko-pomorskim - średnio 8,0\%, lokalnie 10,0-18,0\% (Włocławek, Radziejów, Inowrocław, Chełmno, Tuchola), 77,0\% (Świecie), 100,0\% (Brodnica); dolnośląskim - średnio 7,6\%, lokalnie 15,0-18,0\% (Wałbrzych, Oleśnica, Ząbkowice Śląskie), 21,0-25,0\% (Świdnica, Środa Śląska, Dzierżoniów, Kłodzko), 35,0\% (Jelenia Góra); małopolskim - średnio $7,4 \%$, a lokalnie 10,0-16,0\% (Pszczyna, Nowy Sącz, Limanowa), 20,0-25,0\% (Bochnia, Oświęcim, Myślenice), 30,0\% (Tarnów), 40,0\% (Zakopane); lubelskim - 6,8\% (lokalnie w oddziałach terenowych 69,0\% - Radzyń Podlaski, 12,0-18,0\% - Parczew, Tomaszów Lubelski, Biała Podlaska, Zamość); Piotrków Trybunalski i Łódź 9,7\% (województwo łódzkie, a lokalnie 10,0-15,0\% Wieluń, Wieruszów, Łask, Łódź, Tomaszów Mazowiecki); Radom - 12,0\% i Siedlce - 9,3\% (województwo mazowieckie, a lokalnie 13,0-14,0\% - Płońsk, Ostrów Mazowiecka, 28,0\% - Łosice, 58,0\% - Radom); Rzeszów - 8,2\% (województwo podkarpackie, a lokalnie 10,014,0\% - Dębica, Przemyśl, Ropczyce, Jarosław, 17,020,0\% Mielec, Strzyżów, Leżajsk); Kalisz - 10,3\% (województwo wielkopolskie, a lokalnie 11,0-13,0\% - Kępno, Gniezno, Nowy Tomyśl, Chodzież).

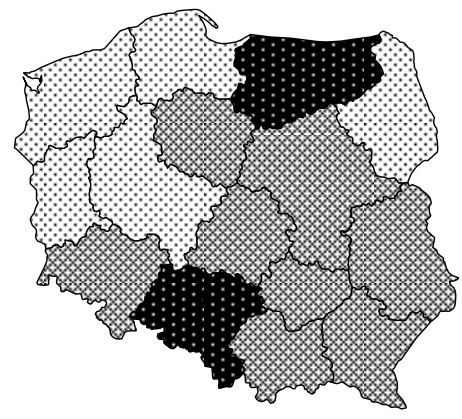

Rys. 7. Skrzypionki - Oulema spp.

$\%$ uszkodzonych źdźbeł pszenicy ozimej $\%$ damaged stems of winter wheat Brak danych - Data not available $4,3-6,5$ $6,6-8,0$ $8,1-11,0$ 
Ponadto o lokalnie większej szkodliwości informowano z województw: lubuskiego, gdzie na terenie oddziałów terenowych: Międzyrzecz, Nowa Sól, Gorzów Wielkopolski stwierdzono 11,0-19,0\% uszkodzonych źdźbeł pszenicy ozimej, 31,0\% - Świebodzin; podlaskiego 10,0-13,0\% (Sokółka, Siemiatycze, Hajnówka); pomorskiego - 10,0-13,0\% (Kwidzyń, Starogard Gdańsk), 32,0\% (Bytów); zachodniopomorskiego - 12,0-15,0\% (Drawsko Pomorskie, Goleniów), 20,0-21,0\% (Stargard Szczeciński, Gryfice), natomiast średnio w tych województwach odnotowano najmniej uszkodzonych źdźbeł $(4,3-5,3 \%)$.

Informacje dotyczące występowania skrzypionek na pszenicy jarej przekazano z pięciu województw, tj.: łódzkiego, gdzie odnotowano średnio 5,0\% uszkodzonych źdźbeł, mazowieckiego - średnio 3,0\%, a lokalnie 4,0\% (Mława), podlaskiego - średnio 2,4\%, a lokalnie 5,0-9,0\% (Łomża, Kolno), lubuskiego - średnio 2,0\%, pomorskiego - średnio 2,0\%, a lokalnie 5,0\% (Kościerzyna).

\section{Mszyca czeremchowo-zbożowa - Rhopalosiphum padi L.}

W roku 2013, w skali całego kraju, opanowanych zostało średnio 3,0\% źdźbeł pszenicy ozimej. Jest to wartość mniejsza o $1,6 \% \mathrm{w}$ porównaniu do odnotowanej w roku 2012, a w stosunku do średniej wieloletniej o 2,6\%.

Dużą liczebność mszycy czeremchowo-zbożowej ob.serwowano w województwach: śląskim, gdzie średnio szkodnik opanował 5,0\% źdźbeł, zachodniopomorskim $4,8 \%$ i kujawsko-pomorskim - 3,9\%.

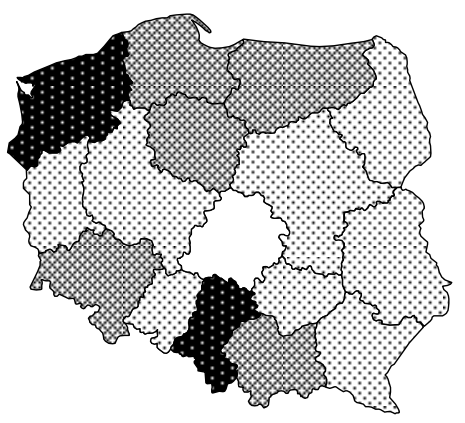

Rys. 8. Mszyca czeremchowo-zbożowa R. padi $\mathrm{L}$.

$\%$ opanowanych źdźbeł pszenicy ozimej $\%$ damaged stems of winter wheat

\begin{tabular}{|c|c|}
\hline & Brak danych - Data not available \\
\hline & $1,2-3,0$ \\
\hline 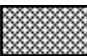 & $3,1-4,0$ \\
\hline$: \vdots: \vdots$ & $4,1-5,0$ \\
\hline
\end{tabular}

Najmniej licznie szkodnik wystąpił na terenie województw: podkarpackiego i podlaskiego, opanowując średnio $1,2 \%$ źdźbeł oraz lubuskiego - 1,5\%. W pozostałych województwach średni procent źdźbeł opanowanych przez szkodnika mieścił się w przedziale od 2,7 (województwo wielkopolskie i mazowieckie) do 3,4\% (małopolskie).
Największą liczebność szkodnika obserwowano lokalnie w takich oddziałach terenowych, jak: Gryfice - 30,0\% opanowanych źdźbeł (województwo zachodniopomorskie); Jelenia Góra - 25,0\% (województwo dolnośląskie); Staszów - 19,0\% (województwo świętokrzyskie); Kwidzyń 15,0\% (województwo pomorskie); Biała Podlaska - 14,0\% (województwo lubelskie); Brodnica - 14,0\% (województwo kujawsko-pomorskie) i Łosice - 13,0\% (województwo mazowieckie).

Informacje o występowaniu szkodnika na pszenicy jarej przekazano z 2 województw: lubuskiego, gdzie średnio odnotowano $4,0 \%$ opanowanych źdźbeł, lokalnie $6,0 \%$ Żagań oraz podlaskiego - 1,9\%, lokalnie 8\% - Kolno.

Na podstawie odłowów mszyc aspiratorem Johnsona w trzech miejscowościach w Polsce w roku 2013: Sośnicowice (województwo śląskie), Białystok (województwo podlaskie) i Winna Góra (województwo wielkopolskie) stwierdzono początek migracji wiosennej mszycy czeremchowo-zbożowej w dniach od 20 maja do 15 czerwca w czasie, gdy pszenica ozima była w fazie krzewienia lub strzelania w źdźbło. We wszystkich trzech miejscowościach mszyca czeremchowo-zbożowa, podobnie jak w latach ubiegłych, należała do najliczniej odławianych gatunków, osiągając w proporcji do wszystkich odławianych aspiratorem mszyc wartości: 6,6\% (Sośnicowice), 6,9\% (Białystok) i 32,0\% (Winna Góra).

\section{Mszyca zbożowa - Sitobion avenae F.}

W roku 2013 rejestrowana na pszenicy ozimej mszyca zbożowa w skali kraju zasiedlała średnio 4,8\% źdźbeł, co było wartością mniejszą niż odnotowana w roku 2012 o $1,2 \%$, natomiast $\mathrm{w}$ stosunku do średniej wieloletniej mniejszą o $2,3 \%$.

Licznie mszyca zbożowa wystąpiła w województwach: dolnośląskim, gdzie średnio opanowała 8,4\% źdźbeł pszenicy ozimej, opolskim - 7,7\% (oddział terenowy Brzeg $39,0 \%$ ) i warmińsko-mazurskim - 7,2\% (Giżycko $50,0 \%)$.

Najliczniejsze zasiedlenie źdźbeł pszenicy ozimej przez mszycę zbożową obserwowano lokalnie w takich oddziałach terenowych, jak: Starogard Gdański - 100\% (województwo pomorskie); Świdnica - 85\%, Strzelin - 60\%, Wałbrzych - 47\% (województwo dolnośląskie); Zawiercie - $61 \%$ (województwo śląskie); Giżycko - 50\% (województwo warmińsko-mazurskie).

Najmniej licznie mszyca ta wystąpiła w województwach: mazowieckim, opanowując średnio 1,5\% źdźbeł i podlaskim $-1,7 \%$. W pozostałych województwach stopień zasiedlenia źdźbeł pszenicy ozimej wyniósł: od 3,0\% (województwo lubelskie i lubuskie) do 5,9\% (województwo kujawsko-pomorskie).

Informacje o wystąpieniu mszycy zbożowej na pszenicy jarej przekazano z 3 województw: pomorskiego, gdzie średnio opanowanych zostało 5,0\% źdźbeł, podlaskiego $3,2 \%$, a lokalnie $16 \%$ - w oddziale terenowym Kolno oraz łódzkiego - $2,1 \%$.

W odłowach aspiratorem Johnsona w Winnej Górze, Białymstoku i Sośnicowicach początek migracji stwierdzono w okresie od 18 maja (Białystok) do 30 maja (Winna Góra). W tym czasie pszenica ozima znajdowała się w fazie strzelania w źdźbło. Najliczniejsze migracje tego 
gatunku miały miejsce w okresie wiosny. Odłowy mszycy zbożowej w 2013 roku wyniosły na tle ogólnej liczby odłowionych mszyc od 1,8 (Sośnicowice) do 5,0\% (Winna Góra).

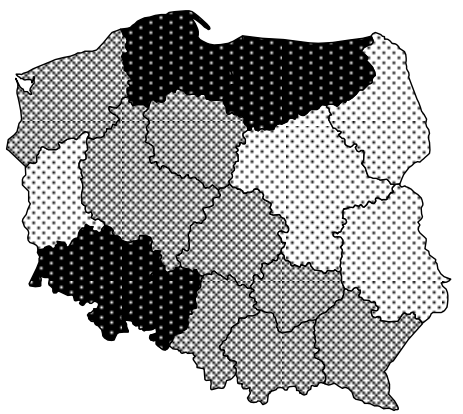

Rys. 9. Mszyca zbożowa S. avenae $\mathrm{F}$.

$\%$ opanowanych kłosów pszenicy ozimej $\%$ damaged stems of winter wheat

\begin{tabular}{l}
\hline Brak danych - Data not available \\
$1,5-3,0$ \\
$3,1-7,0$ \\
$7,1-8,7$
\end{tabular}

Pryszczarek zbożowiec - Haplodiplosis equestris Wagn.

Średnia liczba źdźbeł pszenicy ozimej z objawami żerowania szkodnika, na podstawie przeprowadzonych obserwacji w roku 2013 (poza województwami: dolnośląskim, opolskim i łódzkim), wynosiła w skali kraju 1,5\% uszkodzonych źdźbeł pszenicy ozimej analogicznie do roku 2012 i kształtowała się minimalnie poniżej poziomu średniej z wielolecia, która wynosi 1,7\%.

W przypadku pryszczarka zbożowca trzeba mieć na uwadze fakt, że liczniejsze jego występowanie determinują odpowiednie warunki: temperatura, wilgotność powietrza i typ gleby. Stąd szkody powodowane przez omawiany gatunek mają charakter lokalny i od lat związane są $\mathrm{z}$ określonymi stałymi rejonami Polski (w minionych latach głównie południowa Polska i rejony Żuław Wiślanych). Jednak w roku 2013, podobnie jak w kilku wcześniejszych latach, większą jego szkodliwość stwierdzano również w rejonie centralnej i północno-zachodniej Polski.

W skali województw największą liczbę uszkodzonych źdźbeł odnotowano w województwie zachodniopomorskim - średnio 3,0\%, a lokalnie w oddziałach terenowych 7,0 $12,0 \%$ (Gryfice, Stargard Szczeciński, Goleniów); lubuskim - średnio 2,8\%, a lokalnie 7,0-8,0\% (Wschowa i Nowa Sól) i 22,0\% (Żagań); warmińsko-mazurskim średnio także 2,8\%, a lokalnie 5,0-8,0\% (Ełk, Braniewo, Giżycko, Bartoszyce) i 16,0\% (Elbląg i Kętrzyn) oraz małopolskim - średnio 2,4\%, a lokalnie w oddziałach terenowych 5,0-12,0\% (Bochnia, Tarnów, Gorlice, Proszowice, Nowy Sącz) i 17,0\% (Limanowa).

Powyżej 1\% uszkodzonych źdźbeł pszenicy ozimej średnio dla województwa odnotowano w: kujawsko-po- morskim, gdzie uszkodzonych zostało średnio 1,5\% źdźbeł (lokalnie Bydgoszcz, Lipno, Świecie, Inowrocław - 4,0-5,0\%, Wąbrzeźno - 9,0\%); lubelskim - średnio 1,4\% (lokalnie Lublin - 4,0\% i 20\% - Opole Lubelskie); śląskim - średnio 1,3\% (lokalnie 5,0\% - Pszczyna).

Najmniejsze zagrożenie stanowił pryszczarek zbożowiec w województwach: podlaskim, gdzie uszkodził średnio $0,5 \%$ źdźbeł pszenicy ozimej i tylko lokalnie więcej w oddziałach terenowych $-3,0-8,0 \%$ (Bielsk Podlaski, Hajnówka, Białystok, Siemiatycze); świętokrzyskim $0,7 \%$ i wielkopolskim $-0,9 \%$.

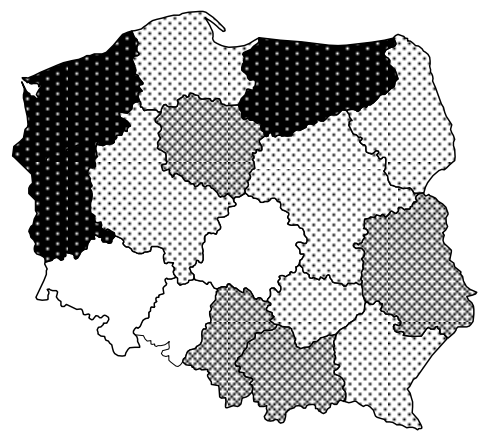

Rys. 10. Pryszczarek zbożowiec H. equestris Wagn.

$\%$ uszkodzonych źdźbeł pszenicy ozimej \% of damaged stems of winter wheat

\begin{tabular}{ll}
\hline & Brak danych - Data not available \\
& $0,5-1,0$ \\
&
\end{tabular}

Lokalnie duży procent uszkodzonych źdźbeł stwierdzono ponadto na terenach oddziałów: Ciechanów $-4,0 \%$, Przysucha - 6,0\% (województwo mazowieckie); Nisko 4,0\% (województwo podkarpackie), Starogard Gdański $12 \%$ (województwo pomorskie), Kępno - 8\% (województwo wielkopolskie.

\section{Kukurydza-Maize}

\section{Fuzariozy kolb kukurydzy - Fusarium spp.}

Rok 2013 jest kolejnym, szóstym rokiem, w którym występowanie grzybów rodzaju Fusarium powodujących fuzariozy kolb kukurydzy zostało objęte rejestracją szczegółową.

Porażenie kolb kukurydzy przez Fusarium spp. Notowano na terenie 11 województw (poza łódzkim, pomorskim, świętokrzyskim, zachodniopomorskim i warmińskomazurskim) w średnio wyższym nasileniu $(2,4 \%$ porażonych kolb kukurydzy), w porównaniu do sezonu wegetacyjnego $2012(1,7 \%)$.

Większe nasilenie choroby na kolbach kukurydzy, powyżej średniej krajowej, rejestrowano w wojewódz- 
twach: dolnośląskim - średnio $6,8 \%$ porażonych kolb kukurydzy, lokalnie 30,0-35,0\% (Lubań, Świdnica i Kłodzko); opolskim - średnio 5,7\%, lokalnie 22,0\% (Brzeg), $18,0 \%$ (Nysa), 11,0\% (Kluczbork); kujawsko-pomorskim średnio 4,1\%, lokalnie $82,0 \%$ (Świecie); wielkopolskim średnio 3,2\%, lokalnie 10,0-12,0\% (Kościan i Leszno); lubuskim - średnio 2,8\% oraz lubelskim - średnio 2,5\%, lokalnie 10,0-20,0\% (Puławy, Kraśnik, Biłgoraj). Na terenie pozostałych województw odnotowano od $0,2 \%$ porażonych kolb kukurydzy (śląskie) do 2,0\% (podkarpackie).

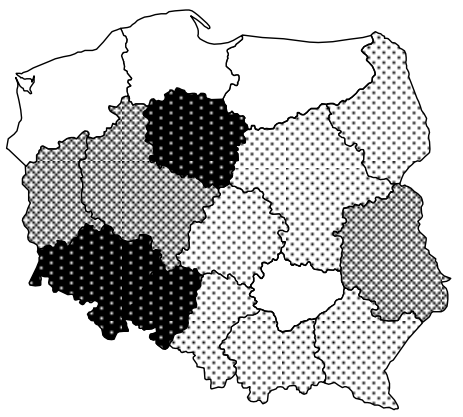

Rys. 11. Fuzariozy kolb kukurydzy Fusarium spp.

$\%$ porażonych kolb kukurydzy

$\%$ infected cobs of maize

\begin{tabular}{|c|c|}
\hline & Brak danych - Data not available \\
\hline - & $0,0-2,0$ \\
\hline 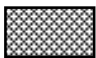 & $2,1-4,0$ \\
\hline & $4,1-6,8$ \\
\hline
\end{tabular}

Ploniarka zbożówka - Oscinella frit L. i O. puzilla Meig.

Od roku 2006, po wielu latach przerwy, a w roku 2013 po raz ósmy, oceniano jaki procent roślin kukurydzy został uszkodzony przez ploniarkę zbożówkę w Polsce. Stwierdzono, że średnio w skali kraju uszkodzonych zostało $1,7 \%$ roślin i było to o $0,9 \%$ mniej niż w roku 2012 . Od roku 2008 szkodliwość tego gatunku na kukurydzy kształtuje się poniżej średniej z wielolecia $(3,4 \%)$.

Tylko w województwie zachodniopomorskim stwierdzono zwiększenie liczby uszkodzonych roślin w stosunku do roku 2012 (z 0,0 do 3,3\%), natomiast w województwach mazowieckim i świętokrzyskim szkodliwość utrzymała się na tym samym poziomie, a w pozostałych, w porównaniu do wyników uzyskanych w roku 2012, szkodnik uszkodził mniej roślin.

Liczba uszkodzonych roślin powyżej średniej krajowej $(1,7 \%)$ została odnotowana w wymienionym już województwie zachodniopomorskim - średnio 3,3\% lokalnie w oddziałach terenowych 6,0-8,0\% (Gryfino, Drawsko Pomorskie), a ponadto: dolnośląskim - średnio 2,8\% lokalnie 5,0-10,0\% (Lwówek Śląski, Ząbkowice Śląskie, Głogów, Wałbrzych, Góra i Oława), 15,0-20,0\% (Oleśnica, Środa Śląska); warmińsko-mazurskim - średnio 2,8\%, lokalnie 5,0-7,0\% (Braniewo i Ostróda), 21,0\% (Giżycko); kujawsko-pomorskim - średnio 2,7\%, a lokalnie 5,0-9,0\% (Inowrocław, Wąbrzeźno, Bydgoszcz), 17,0-22,0\% (Tuchola, Świecie); lubuskim - średnio 2,5\%, lokalnie 5,0-11,0\% (Słubice, Krosno Odrzańskie, Międzyrzecz, Żagań, Sulęcin), 15,0-18,0\% (Strzelce Krajeńskie, Świebodzin); łódzkim - średnio 2,0\%, a lokalnie 5,0\% (Bełchatów i Tomaszów Mazowiecki); podlaskim - średnio 1,9\%, lokalnie 5,0-10,0\% (Grajewo, Siemiatycze, Bielsk Podlaski, Hajnówka, Mońki) oraz w województwie lubelskim - 1,6\%, lokalnie: 5,0-11,0\% (Chełm, Lublin, Biała Podlaska, Łuków); województwie mazowieckim 1,5\%, lokalnie: 7,0-15,0\% (Kozienice, Sokołów Podlaski, Radom); województwie wielkopolskim - 1,5\%, lokalnie 5,0-7,0\% (Jarocin, Leszno, Oborniki, Chodzież); województwie śląskim - 0,8\%, lokalnie 10,0\% (Cieszyn).

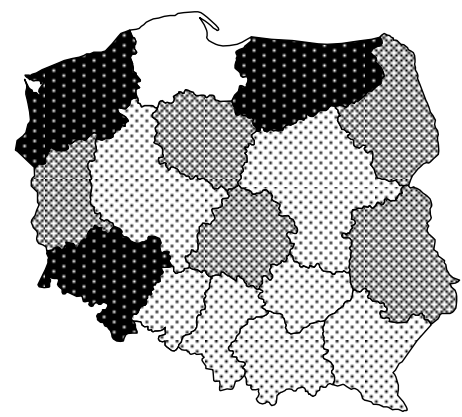

Rys. 12. Ploniarka zbożówka O. frit L. i O. puzilla Meig.

$\%$ uszkodzonych roślin kukurydzy $\%$ of damaged maize plants

$\square$ Brak danych - Data not available

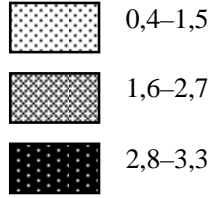

\section{Omacnica prosowianka - Ostrinia nubilalis $\mathrm{Hbn}$.}

Od 1991 roku szkodliwość omacnicy prosowianki monitorowana była tylko w niektórych latach. Ze względu na coraz większy areał uprawy kukurydzy w Polsce od roku 2006 procent uszkodzonych roślin kukurydzy przez omacnicę oceniany jest systematycznie. W roku 2013 obserwacje prowadzone były powszechnie, poza województwem pomorskim. W skali kraju średnio uszkodzonych zostało $5,1 \%$ roślin i w stosunku do oceny szkodliwości omacnicy prosowianki przeprowadzonej w roku $2012(5,1 \%)$, stwierdzono taki sam poziom szkodliwości. Dla porównania średnia wieloletnia, obliczona na podstawie obserwacji, które miały miejsce na przestrzeni lat 1991-2013, wynosi 5,8\% uszkodzonych roślin.

Nieznaczne zwiększenie się średniej szkodliwości tego gatunku (o około 2,0\%) odnotowano w województwach: kujawsko-pomorskim z 1,9 do 4,6\% uszkodzonych roślin, łódzkim z 1,7 do 4,3\%, zachodniopomorskim z 1,9 do 4,3\%, lubelskim z 5,7 do 8,0\%. Szkodliwość omacnicy prosowianki powyżej wartości średniej krajowej $(5,1 \%)$ 
odnotowano w województwach: świętokrzyskim, gdzie uszkodzonych zostało średnio 13,0\% roślin kukurydzy, a lokalnie 21,0\% (Jędrzejów); opolskim - 9,2\%, a lokalnie $15,0 \%$ (Opole), 24,0\% (Namysłów), 34,0\% (Strzelce Opolskie); podkarpackim - 8,7\%, lokalnie 15,0\% (Krosno, Przeworsk, Ropczyce), 19,0\% (Jarosław i Przemyśl), 23,0\% (Strzyżów), 29,0\% (Mielec), 35,0\% (Rzeszów); lubelskim $-8,0 \%$, a lokalnie 15,0\% (Zamość i Włodawa), 23,0\% (Biała Podlaska), 26,0\% (Tomaszów Lubelski), 30,0\% (Biłgoraj i Łuków); dolnośląskim - 6,4\%, a lokalnie 15,0-20,0\% (Wałbrzych, Strzelin, Góra, Oleśnica, Wołów), 22,0\% (Środa Śląska), 32,0\% Dzierżoniów); lubuskim - 5,7\%, a lokalnie 18,0-26,0\% (Świebodzin, Żagań, Wschowa).

W pozostałych województwach średni procent uszkodzonych roślin wahał się od 0,7 (warmińsko-mazurskie) do 4,9\% (śląskie).

Dużą szkodliwość odnotowano lokalnie na terenach oddziałów: Świecie, gdzie stwierdzono 41,0\% uszkodzonych roślin kukurydzy (województwo kujawsko-pomorskie), Bełchatów - 15,0\% (województwo łódzkie), Tarnów 20,0\% (województwo małopolskie), Radom - 18,0\%, Kozienice - 22,0\%, Płock - 25,0\%, Ostrów Mazowiecka 28,0\%, Łosice - 45,0\% (województwo mazowieckie), Siemiatycze - 20,0\% (województwo podlaskie), Pszczyna - 15,0\%, Cieszyn - 20\%, Częstochowa i Lubliniec $50,0 \%$, Gliwice - 52,0\% (województwo śląskie), Wągrowiec-15,0\% (województwo wielkopolskie).

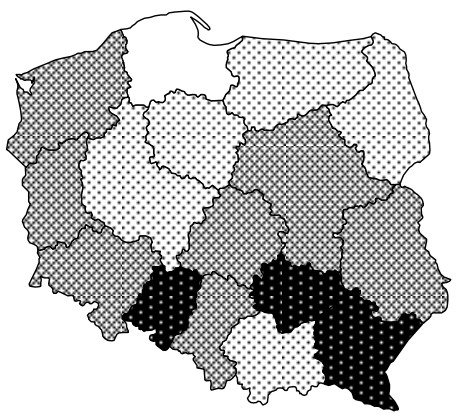

Rys. 13. Omacnica prosowianka O. nubilalis $\mathrm{Hbn}$.

$\%$ uszkodzonych roślin kukurydzy $\%$ of damaged maize plants

\begin{tabular}{ll}
\hline & Brak danych - Data not available \\
\hline $\mathrm{r}$ & $0,7-4,0$ \\
$4,1-8,0$ \\
$8,1-13,0$
\end{tabular}

\section{Choroby i szkodniki roślin okopowych Diseases and pests of root crops}

\section{Ziemniak - Potato}

\section{Zaraza ziemniaka - Phytophthora infestans (Mont.) de Bary}

Zaraza ziemniaka w roku 2013 wystapiła w średnim nasileniu, podobnie jak w latach 2008 i 2010. Chorobę obserwowano na plantacjach ziemniaka na terenie całego kraju, a średnia liczba porażonych roślin wyniosła $25,2 \%$, ale była mniejsza od wartości średniej krajowej odnotowanej w roku 2012 o 5,1\% i kształtowała się poniżej poziomu średniej wieloletniej obliczonej na podstawie średnich krajowych na przestrzeni lat 1991-2013, która wynosi $44,0 \%$ porażonych roślin ziemniaka.

Największe nasilenie choroby (powyżej 30,0\%) stwierdzono w następujących województwach: małopolskim, w którym średnio obserwowano $54,6 \%$ porażonych roślin ziemniaka, lokalnie 60,0-95,0\% (oddział terenowy w: Olkuszu, Gorlicach i Tarnowie) oraz 100\% (w Bochni, Limanowej, Nowym Sączu, Oświęcimiu, Suchej Beskidzkiej i Zakopanem); podkarpackim - 52,7\%; śląskim - 42,2\%; warmińsko-mazurskim - 34,9\% oraz w świętokrzyskim $31,7 \%$.

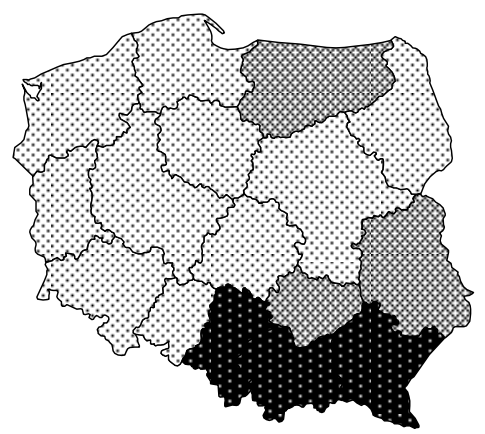

Rys. 14. Zaraza ziemniaka P. infestans (Mont.) de Bary

$\%$ porażonych roślin ziemniaka $\%$ infected potato plants

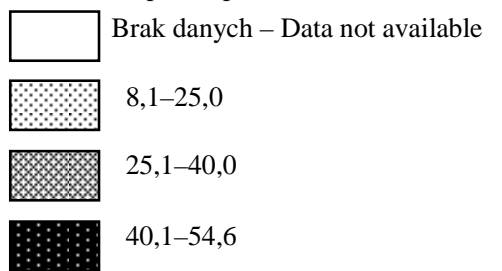

Lokalnie większe nasilenie choroby spowodowane przez $P$. infestans obserwowano w następujących oddziałach terenowych: Świecie - $100,0 \%$ porażonych roślin, Chełmno 50,0\% (województwo kujawsko-pomorskie); Tomaszów Lubelski - 100,0\%, Łuków - 89,0\%, Biłgoraj - 70,0\%, Hrubieszów - 60,0\% i Chełm - 50,0\% (województwo lubelskie); Radom, Siedlce - 100,0\%, Przysucha - 87,0\%, Warszawa - 80,0\%, Łosice 55,0\% i Garwolin - 50,0\% (województwo mazowieckie); Kościerzyna $-100,0 \%$, Słupsk - 80,0\%, Człuchów - 70,0\%, Puck - 50,0\% i Bytów - 40,0\% (województwo pomorskie); Żagań - 95,0\% (województwo lubuskie) oraz lokalnie 40,0 do $90,0 \%$ na terenach następujących oddziałów terenowych: Oleśnica, Głogów, Lubań Śląski, Lubin i Zgorzelec (województwo dolnośląskie); Skierniewice, Bełchatów, Tomaszów Mazowiecki i Brzeziny (województwo łódzkie); Myślenice, Miechów (województwo małopolskie); Głubczyce (województwo opol- 
skie); Jarosław, Ropczyce, Leżajsk (województwo podkarpackie); Mońki, Hajnówka, Sokółka, Białystok (województwo podlaskie); Bytów, Puck i Człuchów (województwo pomorskie); Pszczyna i Lubliniec (województwo śląskie); Kazimierza Wielka, Ostrowiec Świętokrzyski, Jędrzejów (województwo świętokrzyskie); Szczytno, Ełk, Nidzica, Braniewo, Ostróda, Działdowo, Olecko, Pisz, Gołdap (województwo warmińsko-mazurskie); Gniezno, Chodzież i Czarnków (województwo wielkopolskie); Stargard Szczeciński (województwo zachodniopomorskie).

Najmniejsze zagrożenie na monitorowanych plantacjach ziemniaka stanowiła choroba w województwach: opolskim, gdzie liczba roślin z objawami zarazy ziemniaka wynosiła średnio $8,1 \%$, mazowieckim - 9,5\%, zachodniopomorskim $-11,0 \%$, wielkopolskim $-12,3 \%$, podlaskim $14,7 \%$, łódzkim $16,4 \%$ oraz lubuskim $-17,2 \%$.

\section{Stonka ziemniaczana - Leptinotarsa decemlineata Say}

W porównaniu z rokiem 2012 (6,8\%) zwiększyła się szkodliwość stonki ziemniaczanej w skali kraju. Średnia liczba roślin ziemniaka z objawami żerowania szkodnika, na podstawie powszechnie przeprowadzonych obserwacji w roku 2013, wynosiła w skali kraju 8,4\% uszkodzonych roślin, a dla porównania wartość średniej wieloletniej z ostatnich 23 lat wynosi $20,6 \%$.

W roku 2013 aż w 12 województwach stwierdzono średnio zwiększenie procentu uszkodzonych roślin ziemniaka w stosunku do oceny szkodliwości przeprowadzonej w roku 2012, a o więcej niż 3,0\% w: kujawsko-pomorskim (z 6,4 do 15,9\%), a lokalnie odnotowano $81,0 \%$ uszkodzonych roślin na terenie oddziału Świecie, 38,0\% Tuchola; warmińsko-mazurskim (z 10,2 do 13,4\%), a lokalnie 40,0\% - Szczytno, 34,0-36,0\% - Elbląg, Gołdap i Giżycko, 22,0-28,0\% - Działdowo, Nidzica, Nowe Miasto Lubawskie i Ostróda; opolskim (z 3,6 do 6,7\%), a lokalnie 55,0\% - Strzelce Opolskie, 12,0-28,0\% - Brzeg, Głubczyce i Nysa. W 3 województwach (lubelskie, małopolskie, podkarpackie) odnotowano średnio mniejszą liczbę uszkodzonych roślin niż w roku 2012 .

Średnie w województwie uszkodzenie roślin ziemniaka na poziomie średniej krajowej i większe, odnotowano (poza już wymienionymi - kujawsko-pomorskim i warmińsko-mazurskim) w: podkarpackim, gdzie średnio uszkodzonych zostało $10,7 \%$ roślin, a lokalnie $60,0 \%$ (w oddziale terenowym Mielec), 34,0\% (Przemyśl), 15,020,0\% (Tarnobrzeg, Leżajsk, Jarosław, Ustrzyki Dolne, Sanok i Lubaczów); śląskim - średnio 9,8\%, a lokalnie $45,0 \%$ (Gliwice), 35\% (Katowice), 25,0\% (Kłobuck), 18,0-20,0\% (Częstochowa, Zawiercie); świętokrzyskim średnio 9,7\%, a lokalnie 75,0\% (Starachowice), 30,0\% (Końskie), 15,0-20,0\% (Jędrzejów, Staszów i Kielce); podlaskim - średnio 8,7\%, a lokalnie 80,0\% (Sokólka), $50,0 \%$ (Bielsk Podlaski), 30,0\% (Suwałki), 12,0-22,0\% (Wysokie Mazowieckie, Sejny, Hajnówka, Grajewo, Siemiatycze i Augustów).

Stwierdzono, że szkodnik stanowił najmniejsze zagrożenie dla roślin ziemniaka $(4,6 \%)$ w województwie wielkopolskim.

Lokalnie dużą liczbę uszkodzonych roślin (20,0\% i więcej) stwierdzono ponadto $\mathrm{w}$ oddziałach terenowych: Jelenia Góra - 45,0\%, Wrocław - 30,0\% (województwo dolnośląskie); Biała Podlaska - 31,0\%, Puławy i Hrubieszów - 25,0\%, Tomaszów Lubelski - 20,0\% (województwo lubelskie); Krosno Odrzańskie - 50,0\%, Żagań 24,0\%, Gorzów Wielkopolski i Świebodzin - 21,0\% (województwo lubuskie); Bełchatów, Tomaszów Mazowiecki, Brzeziny, Kutno - 20,0\% (województwo łódzkie); Zakopane $-40,0 \%$, Limanowa $-27,0 \%$, Tarnów i Olkusz $-20,0 \%$ (województwo małopolskie); Łosice - 50,0\%, Radom $-40,0 \%$, Siedlce $-20,0 \%$ (województwo mazowieckie); Słupsk - 55,0\% (województwo pomorskie); Drawsko Pomorskie - 20,0\% (województwo zachodniopomorskie).

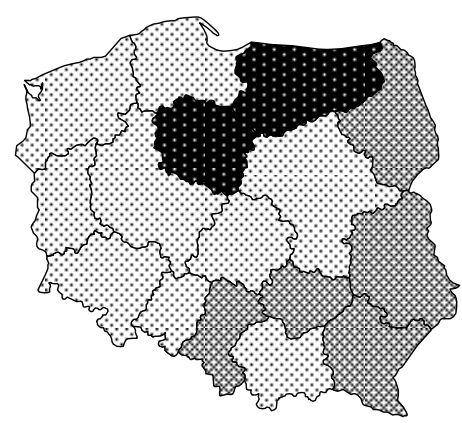

Rys. 15. Stonka ziemniaczana L. decemlineata Say $\%$ uszkodzonych roślin ziemniaka $\%$ of damaged potato plants

\begin{tabular}{ll}
\hline & Brak danych - Data not available \\
$4,8-8,0$ & \\
$8,1-13,0$ & $13,1-15,9$
\end{tabular}

\section{Burakcukrowy-Sugar beet}

\section{Chwościk buraka - Cercospora beticola Sacc.}

Rok 2013, w którym chorobę rejestrowano na terenie 9 województw, charakteryzował się dłuższym okresem infekcji, przypadającym na okres od lipca przez sierpień i wrzesień. Średnia w skali kraju, liczba roślin buraka cukrowego, porażonych chwościkiem buraka wyniosła $15,4 \%$. Wartość ta była o $10,3 \%$ niższa w porównaniu do odnotowanej w roku 2012 i wyższa o $0,7 \%$ od poziomu średniej wieloletniej. Od roku 2007 (19,1\%) znaczenie tej choroby na plantacjach buraka cukrowego zwiększa się, średni procent porażonych roślin kształtuje się powyżej średniej $\mathrm{z}$ wielolecia, która wynosi $14,7 \%$ porażonych roślin.

Dużą liczbę roślin $\mathrm{z}$ objawami chwościka buraka $(12,0 \%$ i powyżej) stwierdzono w województwach: podkarpackim, gdzie średnio porażonych zostało $36,3 \%$ roślin, lokalnie 30,0\% (Lubaczów), 27,0\% (Ropczyce) oraz 15,0\% (Nisko); lubelskim - 21,3\%, a lokalnie: 70,0\% (Hrubieszów), 10,0-12,0\% (Chełm i Kraśnik); dolnośląskim - 15,0\%, a lokalnie 20,0-70,0\% (Góra, Ząbkowice Śląskie, Głogów i Kłodzko); kujawsko-pomorskim - 
13,9\%, lokalnie 100,0\% (Świecie) i 25,0\% (Grudziądz); opolskim - 13,2\%, lokalnie 20,0-30,0\% (Nysa, Prudnik i Namysłów); świętokrzyskim - 13,0\%, lokalnie 30,0\% (Opatów).

Najmniejsze nasilenie choroby na plantacjach buraków obserwowano w województwie zachodniopomorskim, gdzie odnotowano $5,3 \%$ (Szczecin) porażonych roślin buraka cukrowego, lokalnie 15\% (Pyrzyce i Stargard Szczeciński).

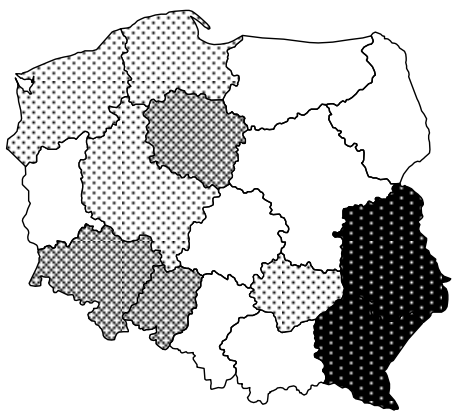

Rys. 16. Chwościk buraka C. beticola Sacc.

$\%$ porażonych roślin buraka cukrowego $\%$ infected sugar beet plants

\begin{tabular}{ll}
\hline Brak danych - Data not available \\
$5,3-13,0$ \\
$20,1-36,3$ \\
$23,1-20,0$
\end{tabular}

\section{Śmietka ćwiklanka - Pegomyia hyoscyami Panz.}

W roku 2013 szkodnik wystąpił na terenie 9 województw, najliczniej w województwie pomorskim, uszkadzając średnio $8,0 \%$ roślin buraka cukrowego. Średnia z 9 województw wyniosła 3,5\% i była o 2,7\% niższa od odnotowanej $\mathrm{w}$ roku 2012, zbliżona do roku 2011 kształtowała się poniżej wartości średniej wieloletniej $(4,6 \%)$, a taka sytuacja miała miejsce w ostatnich latach także w roku 2011.

Podobnie, jak w latach ubiegłych, większą liczbę uszkodzonych roślin odnotowano w wymienionym już województwie pomorskim $(8,0 \%)$, lokalnie $15,0 \%$ (w oddziale terenowym Kwidzyń) oraz: podkarpackim - 6,7\%, lokalnie 25,0\% (Lubaczów); lubuskim - 4,5\%; kujawskopomorskim $-3,3 \%$, lokalnie $15,0 \%$ (Świecie) i $5,0-14,0 \%$ (Żnin, Bydgoszcz, Toruń, Wąbrzeźno, Brodnica i Tuchola); świętokrzyskim - 2,5\%, lokalnie 5,0\% (Opatów); mazowieckim - 2,0\%.

Ponadto, do oddziałów terenowych, w których tylko lokalnie obserwowano większą liczebność śmietki ćwiklanki, należały: Oława - 9,0\%, Góra $-8,0 \%$, Świdnica $6,0 \%$ (województwo dolnośląskie); Leżajsk - 8,0\%, Strzyżów - 6,0\%, Ropczyce - 5,0\% (województwo podkarpackie) oraz Gryfice $-7,0 \%$, Stargard Szczeciński $5,0 \%$ (województwo zachodniopomorskie).
Informacje o uszkodzonych roślinach buraka pastewnego przekazały 2 województwa. Średnio śmietka ćwiklanka uszkodziła w: kujawsko-pomorskim $6,0 \%$ roślin, lokalnie $7,0 \%$ (na terenie oddziału Rypin) oraz małopolskim $-2,0 \%$. Średnia liczba uszkodzonych roślin buraka pastewnego z dwóch województw wyniosła 4,0\%.

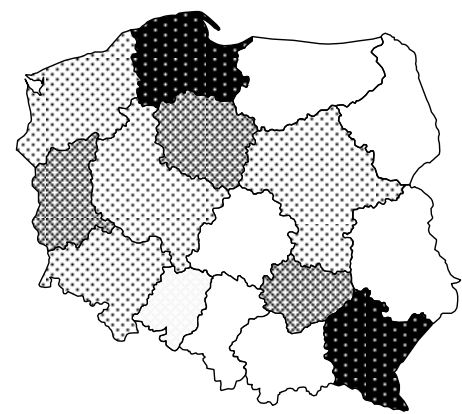

Rys. 17. Śmietka ćwiklanka P. hyoscyami Panz.

$\%$ uszkodzonych roslin buraka cukrowego $\%$ of damaged sugar beet plants

$\square$ Brak danych - Data not available

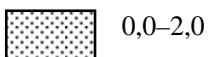

$2,1-5,0$

$5,1-8,0$

\section{Mszyca trzmielinowo-burakowa - Aphis fabae Scop.}

Dane o występowaniu mszycy burakowej na buraku cukrowym w roku 2013 pochodzą z 11 województw. Szkodnik ten zasiedlił średnio 4,0\% roślin buraka cukrowego, co jest wielkością niższą o $4,9 \%$ od analogicznej wartości z roku 2012 i niższą o 5,0\% od poziomu średniej wieloletniej.

Najliczniej szkodnik ten wystapił w województwach: lubuskim, gdzie opanował średnio $8,0 \%$ roślin, dolnośląskim $-5,8 \%$, kujawsko-pomorskim $-5,6 \%$ i zachodniopomorskim - 5,3\%. Najmniej licznie mszycę tę rejestrowano na terenie województw: lubelskiego, odnotowując średnio $1,7 \%$ opanowanych roślin, opolskiego - 2,4\% i wielkopolskiego $-2,5 \%$. Najwięcej opanowanych roślin stwierdzono lokalnie na terenach oddziałów: Kłodzko $50 \%$ i Oława - 20\% (województwo dolnośląskie), Ropczyce - $25 \%$ (województwo podkarpackie) Brodnica $21 \%$ (województwo kujawsko-pomorskie) oraz Gryfice 19,0\% (województwo zachodniopomorskie).

Informacje o wystepowaniu $A$. fabae na buraku pastewnym przekazano tylko $\mathrm{z}$ dwóch województw: kujawsko-pomorskiego, w którym opanowanych zostało $5,0 \%$ roślin oraz małopolskiego $-1,7 \%$.

Na podstawie odłowów aspiratorem Johnsona w Winnej Górze, Białymstoku i Sośnicowicach nalot pierwszych migrantek mszycy A. fabae obserwowano w dniach: 20 maja - Sośnicowice, 27 maja - Białystok oraz 2 czerwca - Winna Góra. Najliczniejszy udział w odłowach aspiratorem $\mathrm{w}$ całym sezonie wegetacyjnym miał ten gatunek 
w Winnej Górze i Białymstoku odpowiednio: 2,1 i 1,4\%, natomiast w Sośnicowicach udział $A$. fabae w odłowach wyniósł zaledwie $0,2 \%$. Są to wartości zbliżone do wyników z roku 2012.

W skali całego sezonu najliczniejsze migracje $A$. fabae na podstawie odłowów aspiratorem w okresie od wiosny do połowy czerwca stwierdzono we wszystkich trzech miejscowościach.

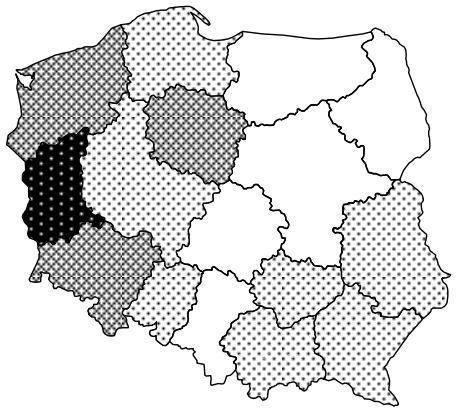

Rys. 18. Mszyca trzmielinowoburakowa - A. fabae Scop. $\%$ opanowanych roślin buraka curowego $\%$ of damaged sugar beet plants

\begin{tabular}{ll}
\hline Brak danych - Data not available \\
$1,0-5,0$ \\
$5,1-7,9$ \\
8,0
\end{tabular}

\section{Choroby i szkodniki roślin przemysłowych Diseases and pests of industrial plants}

\section{Rzepak - Winter rapet}

\section{Sucha zgnilizna roślin kapustnych - Leptosphaeria spp.}

W 2013 roku obserwacje dotyczace oceny szkodliwości suchej zgnilizny kapustnych zostały przeprowadzone, we wszystkich województwach oprócz świętokrzyskiego i łódzkiego. W skali kraju procent porażonych roślin zwiększył się do $5,2 \%$ i była to wartość większa od wartości średniej $\mathrm{z}$ wielolecia $(4,6 \%)$. Zwiększenie nasilenia występowania choroby w roku $2013 \mathrm{w}$ stosunku do 2012 odnotowano w 8 województwach: dolnośląskim, małopolskim, mazowieckim, opolskim, podlaskim, pomorskim, wielkopolskim i zachodniopomorskim.

Rejonami, w których liczba porażonych roślin była większa od średniej krajowej były województwa: warmińsko-mazurskie - 6,2\%, a lokalnie: 35,0\% (Giżycko), $14,0 \%$ (Gołdap), 12,0\% (Nowe Miasto Lubawskie), 10,0\% (Ostróda, Ełk); podlaskie - 6,0\%, lokalnie 24,0\% (Siemiatycze), 10,0\% (Białystok), 6,0\% (Sokółka); zachodniopomorskie $-7,1 \%$, a lokalnie $50,0 \%$ (Drawsko Pomorskie), 3,0\% (Białogard); dolnośląskie - 6,1\%, lokalnie 15\% (Lubań, Środa Śląska), 16,0\% (Zgorzelec) oraz $21,0 \%$ (Strzelin); wielkopolskie $-8,1 \%$, lokalnie
55,0\% (Września), 20,0\% (Oborniki), 18,0\% (Koło, Gniezno), 10,0\% (Konin).

Podobnie, jak w roku ubiegłym, najmniej zagrożone były plantacje rzepaku ozimego w województwie mazowieckim, gdzie objawy suchej zgnilizny roślin kapustnych występowały na średnio 2,3\% roślin.

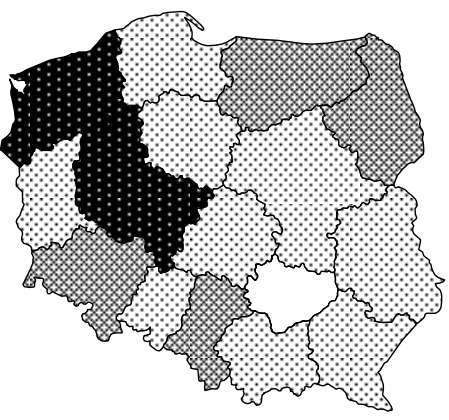

Rys. 19. Sucha zgnilizna roślin kapustnych - Leptosphaeria spp.

$\%$ porażonych roślin rzepaku ozimego $\%$ infected winter oilseed rape plants

\begin{tabular}{|c|c|}
\hline & Brak danych - Data not available \\
\hline & $2,3-5,0$ \\
\hline & $5,1-7,0$ \\
\hline & $7,1-8,1$ \\
\hline
\end{tabular}

\section{Słodyszek rzepakowy - Meligethes aeneus F.}

W roku 2013 obserwacje, dotyczące oceny szkodliwości słodyszka rzepakowego na rzepaku ozimym, zostały przeprowadzone na terenie całego kraju. Średnio w Polsce uszkodzonych zostało 8,2\% pąków kwiatowych (w 2012 roku - 8,9\%). Od roku 1997 średni procent uszkodzonych pąków kwiatowych kształtuje się poniżej poziomu średniej z wielolecia $(11,2 \%)$.

Średnie uszkodzenie pąków kwiatowych rzepaku ozimego większe niż wartość średniej $\mathrm{z}$ wielolecia odnotowano w województwach: podkarpackim - 15,0\%, a lokalnie 40,0\% (Lubaczów) oraz 47,0\% (Strzyżów); śląskim 23,1\%, lokalnie 42,0\% (Gliwice), 25,0\% (Pszczyna), 20,0\% (Cieszyn), 12,0\% (Lubliniec), 10,0\% (Racibórz), $4,0 \%$ (Częstochowa).

W 6 województwach (dolnośląskie, lubuskie, opolskie, podkarpackie, śląskie, zachodniopomorskie) stwierdzono średnio większą liczbę uszkodzonych pąków kwiatowych w porównaniu do oceny szkodliwości przeprowadzonej w roku 2012. W dwóch województwach, tj. lubelskim i małopolskim procent uszkodzonych pąków nie uległ zmianie.

W roku 2013 w Polsce nieznacznie zmniejszyła się średnia szkodliwość słodyszka rzepakowego. Znaczny procent pąków kwiatowych może zostać uszkodzony na tych terenach, gdzie faza pąkowania będzie się wydłużać z powodu warunków pogodowych, niesprzyjających Rozwojowi rzepaku. 


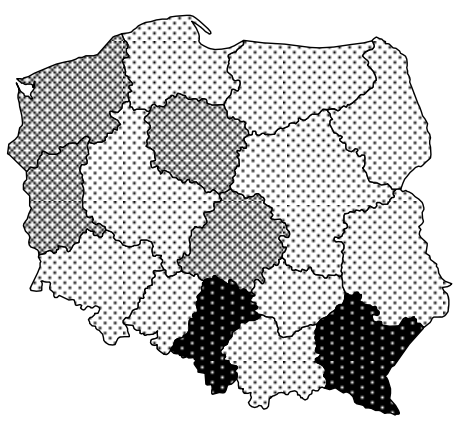

Rys. 20. Słodyszek rzepakowy M. aeneus $\mathrm{F}$.

\% uszkodzonych pąków kwiatowych rzepaku

$\%$ of damaged flower buds of winter oilseed rape

\begin{tabular}{|l}
\hline \\
\hline Brak danych - Data not available \\
$3,0-8,0$ \\
$8,1-14,9$ \\
$15,0-23,1$
\end{tabular}

\section{Chowacz czterozębny - Ceutorhynchus quadridens Panz.}

Uszkodzenia roślin rzepaku w 2013 roku, spowodowane przez chowacza czterozębnego były oceniane we wszystkich województwach. Średnia w skali kraju szkodliwość w stosunku do roku 2012 (5,4\%) zmniejszyła się o $1,2 \%$ i wynosiła 4,4\% uszkodzonych roślin. Od 16 lat

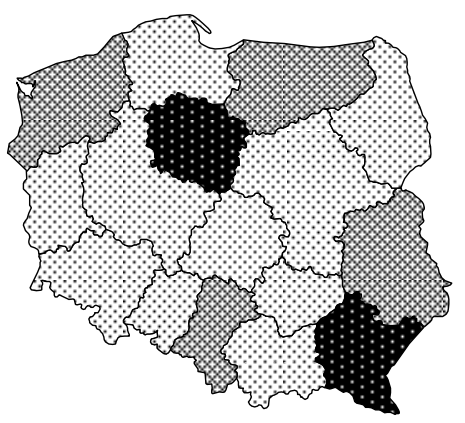

Rys. 21. Chowacz czterozębny C. quadridens Panz.

$\%$ uszkodzonych roślin rzepaku ozimego $\%$ damaged winter oilseed rape plants

\begin{tabular}{ll}
\hline & Brak danych - Data not available \\
$2,0-4,0$ \\
$4,1-7,0$ \\
7
\end{tabular}

średnie dla Polski uszkodzenie roślin kształtuje się poniżej wartości średniej z wielolecia $(13,9 \%)$ i taka sytuacja, zgodnie z ubiegłorocznymi sugestiami prognozowymi, miała także miejsce w roku 2013.

Do województw, w których chowacz czterozębny Spowodował średnie uszkodzenie roślin powyżej średniej krajowej należały: kujawsko-pomorskie - 7,1\%, lokalnie 75,0\% (Świecie), 30,0\% (Grudziądz), 12,0\% (Toruń, Tuchola), 10,0\% (Chełmno, Inowrocław); lubelskie - 4,7\%, lokalnie 25,0\% (Hrubieszów); podkarpackie - 9,4\%, a lokalnie 78,0\% (Strzyżów), 20,0\% (Leżajsk), 19,0\% (Przemyśl), 12,0\% (Lubaczów); śląskie - 9,4\%, lokalnie 14,0\% (Cieszyn), 10,0\% (Lubliniec); warmińsko-mazurskie $-5,5 \%$, a lokalnie 13,0\% (Ostróda), 12,0\% (Elbląg, Giżycko), 11,0\% (Nowe Miasto Lubawskie, Kętrzyn).

Najmniej uszkodzonych roślin odnotowano średnio w województwach: lubuskim $(2,4 \%)$, mazowieckim $(2,0 \%)$, podlaskim $(1,8 \%)$, pomorskim $(2,9 \%)$ oraz wielkopolskim $(2,7 \%)$.

\section{Chowacz brukwiaczek - Ceutorhynchus napi Gyll.}

W 2013 roku obserwacje dotyczące oceny szkodliwości chowacza brukwiaczka prowadzone były na terenie całego kraju. Średnie uszkodzenie roślin rzepaku zmniejszyło się nieznacznie w porównaniu do odnotowanego w roku 2012 $(3,1 \%)$ i wyniosło 2,9\% roślin. Od 1997 roku średnie dla Polski uszkodzenie roślin jest mniejsze od średniej wieloletniej, która wynosi 7,7\%.

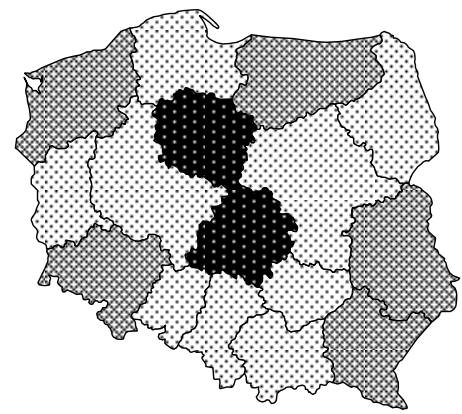

Rys. 22. Chowacz brukwiaczek C. napi Gyll.

$\%$ uszkodzonych roślin rzepaku ozimeg $\%$ damaged winter oilseed rape plants

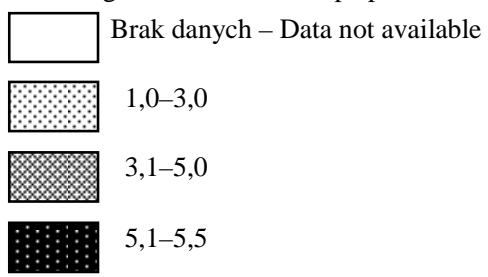

W 7 województwach obserwowano średnio więcej uszkodzonych roślin niż w roku 2012, były to: zachodniopomorskie, lubelskie, lubuskie, łódzkie, opolskie, podkarpackie, podlaskie. Procent uszkodzonych roślin nie uległ zmianie w województwie świętokrzyskim i kształtował się na poziomie $2,5 \%$.

Powyżej 3,0\% uszkodzonych roślin, średnio dla województwa stwierdzono w: dolnośląskim - 3,3\%, lokalnie 10,0-26,0\% (na terenie oddziału: Środa Śląska, Wrocław, 
Oleśnica); kujawsko-pomorskim - 5,5\%, a lokalnie 12,0\% (Toruń, Tuchola), 8,0\% (Chełmno), 6,0\% (Bydgoszcz, Grudziądz, Inowrocław); lubelskim - 3,5\%, lokalnie 5,0\% (Hrubieszów); łódzkim - 5,3\%, a lokalnie 6,0\% (Piotrków Trybunalski), 9,0\% (Pajęczno); podkarpackim - 3,3\%, a lokalnie 22,0\% (Przemyśl), 12,0\% (Lubaczów); warmińsko-mazurskim - 3,7\%, lokalnie $12,0 \%$ (Nowe Miasto Lubawskie), 8,0\% (Ostróda) oraz zachodniopomorskim $-4,8 \%$, a lokalnie $30,0 \%$ (Drawsko Pomorskie), 10,0\% (Goleniów), 9,0\% (Szczecin).

Najmniejszą liczbę uszkodzonych roślin, średnio $1,0-2,5 \%$, odnotowano w województwie: lubuskim $(2,5 \%)$, małopolskim $(1,5 \%)$, mazowieckim $(2,1 \%)$, opolskim $(1,3 \%)$, podlaskim $(1,5 \%)$, pomorskim $(2,0 \%)$, śląskim $(1,0 \%)$ oraz świętokrzyskim i wielkopolskim $(2,5 \%)$.

\section{Chowacz podobnik - Ceutorhynchus assimilis Payk.}

Obserwacje dotyczące oceny szkodliwości chowacza podobnika w roku 2013 zostały przeprowadzone we wszystkich województwach. Średnie dla kraju uszkodzenie łuszczyn w stosunku do odnotowanego w roku 2012 $(4,2 \%)$ zmniejszyło się o $0,6 \%$ i wynosiło $3,6 \%$. Od roku $1999(2,1 \%)$ do $2011(5,4 \%)$ procent uszkodzonych łuszczyn w skali kraju zwiększał się, a w roku 2013 zmniejszył się, mimo to w 5 województwach (dolnośląskie, łódzkie, podkarpackie, śląskie, zachodniopomorskie) odnotowano zwiększenie się procentu uszkodzonych łuszczyn rzepaku ozimego. Średnia krajowa ukształtowała się poniżej średniej z wielolecia $(4,1 \%)$.

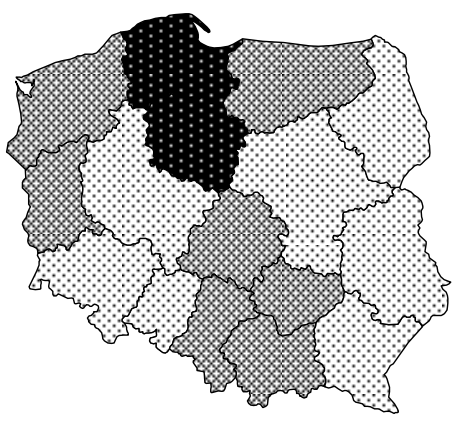

Rys. 23. Chowacz podobnik C. assimilis Payk. $\%$ uszkodzonych łuszczyn rzepaku ozimego $\%$ damaged winter oilseed rape siliques

\begin{tabular}{l}
\hline Brak danych - Data not available \\
$0,0-4,0$ \\
$4,1-6,0$ \\
$6,1-7,0$
\end{tabular}

Szkodliwość chowacza podobnika przekraczająca średnią w skali kraju odnotowano w województwach: Kujawsko-pomorskim, gdzie uszkodzonych zostało średnio 5,0\% łuszczyn, lokalnie 8,0-16,0\% (w oddziałach terenowych: Chełmno, Brodnica, Toruń, Tuchola); lubuskim - 4,1\%, lokalnie 10,0\% (Gorzów Wielkopolski), 9,0\% (Świebo- dzin), 8,0\% (Sulęcin, Nowa Sól), 7,0\% (Strzelce Krajeńskie, Słubice, Krosno Odrzańskie, Lubsko); łódzkim 3,8\%, lokalnie 7,0\% (Piotrków Trybunalski); małopolskim - 4,5\%, lokalnie 4,0-9,0\% (Tarnów, Oświęcim); pomorskim - 5,3\%, lokalnie 80,0\% (Bytów), 9,0-13,0\% (Puck, Nowy Dwór Gdański, Starogard Gdański); śląskim - 4,9\%, lokalnie $12,0 \%$ (Cieszyn), 7,0\% (Lubliniec); zachodniopomorskim $-4,6 \%$, lokalnie 20,0\% (Drawsko Pomorskie), 12,0\% (Choszczno), 10,0\% (Gryfino, Goleniów).

Ponadto dużą szkodliwość chowacza podobnika zaobserwowano lokalnie w oddziałach terenowych, takich jak: Lubaczów, Leżajsk odnotowując odpowiednio 20,0, 19,0\% uszkodzonych łuszczyn (województwo podkarpackie), Bielsk Podlaski - 16,0\% (województwo podlaskie), Kościan - 14,0\%, Oborniki - 15,0\% (województwo wielkopolskie).

\section{Pryszczarek kapustnik - Dasyneura brassicae Winn.}

Ocena szkodliwości pryszczarka kapustnika w 2013 roku została przeprowadzona na terenie całego kraju. Średnio w skali kraju uszkodzenia łuszczyn spowodowane przez szkodnika wyniosły 4,4\% (w 2012 roku - 4,8\%). Zmniejszenie procentu uszkodzonych łuszczyn w stosunku do odnotowanego w roku 2012 nastąpiło w 6 województwach. Od roku 2009 średnie w skali kraju uszkodzenie łuszczyn kształtuje się powyżej średniej z wielolecia, która wynosi $4,2 \%$.

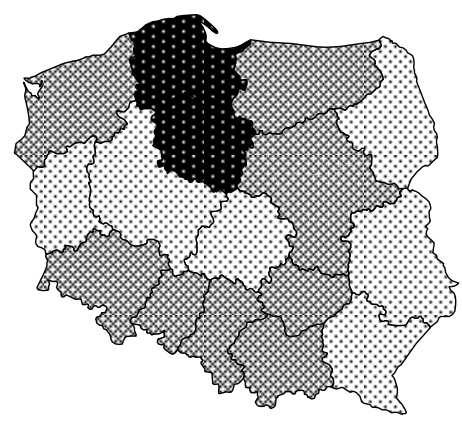

Rys. 24. Pryszczarek kapustnik D. brassicae Winn.

$\%$ uszkodzonych łuszczyn rzepaku ozimego $\%$ damaged winter oilseed rape siliques

$\square$ Brak danych - Data not available

$3,0-4,0$

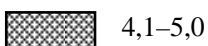

$5,1-6,2$

Największą liczebność szkodnika (powyżej średniej z wielolecia) odnotowano w 7 województwach: kujawskopomorskim, gdzie odnotowano średnio 5,7\% uszkodzonych łuszczyn, a lokalnie 10,0-35,0\% (w oddziałach terenowych: Toruń, Chełmno, Tuchola, Włocławek, Brodnica); małopolskim - 5,0\%, lokalnie 10,0\% (Oświęcim), $5,0 \%$ (Tarnów); mazowieckim - 5,0\%, lokalnie 10,0\% (Sokołów Podlaski); pomorskim - 6,2\%, lokalnie 10,0- 
20,0\% (Starogard Gdański, Bytów, Nowy Dwór Gdański, Słupsk, Człuchów); śląskim - 4,8\%, lokalnie 8,0\% (Pszczyna), 15,0\% (Cieszyn); świętokrzyskim - 4,5\%, lokalnie 2,0\% (Opatów), 8,0\% (Ostrowiec Świętokrzyski); zachodniopomorskim - 5,0\%, lokalnie 7,0\% (Pyrzyce), 8,0\% (Goleniów), 10,0\% (Drawsko Pomorskie), 20,0\% (Choszczno, Szczecin).

Najmniej uszkodzeń odnotowano średnio w województwach: lubelskim - 3,0\%, lokalnie 3,0\% (Chełm), $5,0 \%$ (Hrubieszów); podkarpackim - 3,3\%, lokalnie 16,0\% (Leżajsk, Lubaczów), 4,0\% (Strzyżów, Rzeszów).

W przypadku województwa lubelskiego i małopolskiego wartość uszkodzeń utrzymała się na takim samym poziomie, jak w roku 2012 i wyniosła odpowiednio 3,0 oraz $5,0 \%$.

\section{Choroby i szkodniki roślin warzywnych Diseases and pests of vegetable plants Pom idor - Tom a to}

\section{Zaraza ziemniaka - Phytophthora infestans (Mont.) de Bary}

Informacje o występowaniu zarazy ziemniaka i porażeniu owoców pomidora w roku 2013 nadesłano z 5 województw. W porównaniu z występowaniem choroby w roku 2012 stwierdzono nieznaczne zmniejszenie jej nasilenia ze średnio 3,3 do 2,5\% porażonych owoców. Średni procent porażonych owoców w 2013 roku był nadal (od roku 2002) mniejszy od wartości średniej wieloletniej $(13,9 \%)$ o 11,4.

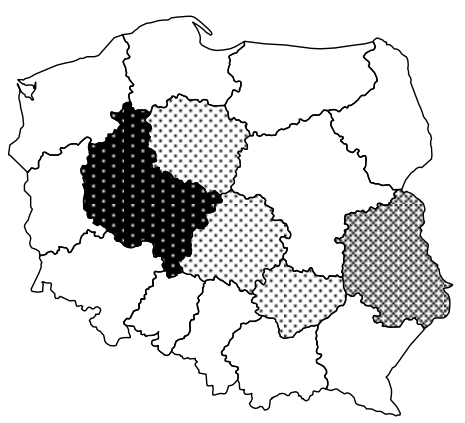

Rys. 25. Zaraza ziemniaka - P. infestans (Mont.) de Bary

$\%$ porażonych owoców pomidora $\%$ infected tomato fruits

\begin{tabular}{ll}
\hline Brak danych - Data not available \\
$1,0-2,0$ \\
$2,1-3,0$ \\
5,4
\end{tabular}

Największe zagrożenie dla roślin pomidora ze strony patogena w roku 2013 odnotowano na terenie województwa wielkopolskiego, gdzie średnio porażonych zostało 5,4\% owoców, lokalnie 11,0\% (Pleszew), 6,0\% (Międzychód), 5,0\% (Gostyń).
Ponadto informacje o porażeniu owoców pomidora przez zarazę ziemniaka nadesłano z województw: lubelskiego - 3,0\%, lokalnie 5,0\% (Łęczna); łódzkiego - 2,0\%, lokalnie 5,0\% (Łowicz); kujawsko-pomorskiego - 1,0\%, lokalnie 2,0\% (oddział terenowy Grudziądz) i świętokrzyskiego - 1,0\%, lokalnie 2,0\% (Sandomierz).

\section{Ogórek - Cucumber}

\section{Mączniak rzekomy dyniowatych - Pseudoperonospora cubensis (Berk. et Curt.) Rostovzev}

W roku 2013 odnotowano większe nasilenie występowania mączniaka rzekomego na ogórku niż w roku 2012. Średnio (na podstawie informacji przekazanych z 9 województw) porażonych zostało $24,5 \%$ roślin i było to o $15,7 \%$ więcej niż w roku 2012. Dla porównania średnia $\mathrm{z}$ wielolecia dla tego patogena wynosi $29,6 \%$ porażonych roślin. Większe nasilenie występowania choroby odnotowano na terenie południowo-wschodniej Polski.

Średnio dla województwa największe nasilenie występowania mączniaka rzekomego dyniowatych stwierdzono na terenie województwa podkarpackiego, gdzie porażonych zostało $100,0 \%$ roślin ogórka (oddział terenowy Mielec).

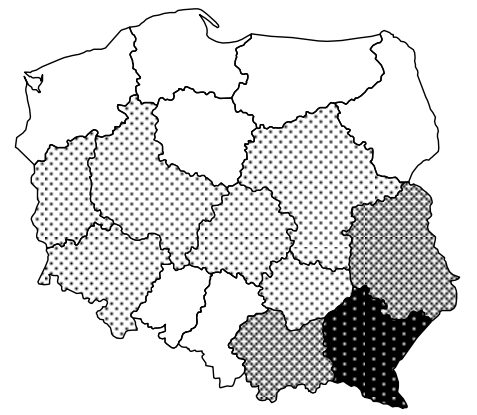

Rys. 26. Mączniak rzekomy dyniowatych $-P$. cubensis (Berk. et Curt.) Rostovzev

$\%$ porażonych roślin ogórka $\%$ infected cucumber plants

\begin{tabular}{ll}
\hline & Brak danych - Data not available \\
$3,0-20,0$ \\
$20,1-42,0$ \\
100,0
\end{tabular}

Większe nasilenie choroby stwierdzono ponadto w województwach: małopolskim, gdzie odnotowano średnio $42,0 \%$ porażonych roślin, lokalnie $100,0 \%$ (na terenie oddziału Nowy Sącz); lubelskim - 22,0\%, lokalnie 32,0\% (Biała Podlaska); wielkopolskim - 15,0\%, lokalnie 37,0\% (Kalisz); łódzkim - 12,6\%, lokalnie 40,0\% (Brzeziny), 25,0\% (Sieradz), 19,0\% (Bełchatów), 15,0\% (Skierniewice), 14,0\% (Łęczyca); świętokrzyskim - 11,5\%, lokalnie 35,0\% (Pińczów), 25,0\% (Busko Zdrój), 20,0\% (Kazi- 
mierza Wielka); lubuskim - 8,0\%, lokalnie 12,0\% (Nowa Sól).

W roku 2013 najmniejsze nasilenie choroby odnotowano w województwie: dolnośląskim - $6,5 \%$ porażonych roślin, więcej lokalnie - 24,0\% (Dzierżoniów) i 8,0\% (Ząbkowice Sląskie); mazowieckim - 3,0\%, lokalnie 24,0\% (Kozienice), 10,0\% (Nowy Dwór Mazowiecki), 5,0\% (Grodzisk Mazowiecki).

\section{Kanciasta plamistość liści ogórka - Pseudomonas syringae pv. lachrymans (Sm. et B.) Young}

W roku 2013 informacje o porażeniu roślin ogórka przez kanciastą plamistość liści nadesłano z 9 województw. Średnio odnotowano $15,8 \%$ porażonych liści i była to wartość nieznacznie większa od średniej wieloletniej, która wynosi 14,0\% oraz w porównaniu do analogicznych wyników obserwacji przeprowadzonych w roku $2012(12,2 \%)$.

Największe nasilenie choroby odnotowano na terenie województwa lubelskiego, gdzie porażonych zostało średnio $39,0 \%$ liści ogórka (lokalnie w oddziale terenowym Biała Podlaska - 50,0\%); podkarpackiego - 28,0\% (lokalnie Mielec-45,0\%).

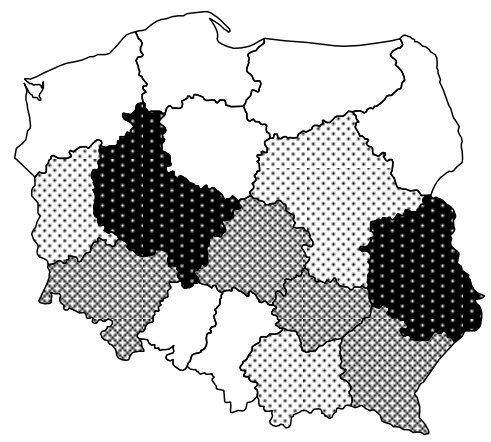

Rys. 27. Kanciasta plamistość liści ogórka - P. syringae pv. lachrymans (Sm. et B.) Young

$\%$ porażonych liści ogórka

$\%$ infected cucumber leaves

\begin{tabular}{ll}
\hline & Brak danych - Data not available \\
$3,3-12,0$ \\
$12,1-23,0$ \\
$23,1-39,0$
\end{tabular}

Większą liczbę porażonych liści stwierdzono średnio w województwach: wielkopolskim - 24,0\%, lokalnie $36,0 \%$ (Kalisz); świętokrzyskim - 17,5\%, lokalnie 37,0\% (Busko Zdrój), 35,0\% (Pińczów) i 25,0\% (Kazimierza Wielka); podkarpackim - 16,0\%, lokalnie 26,0\% (Mielec); łódzkim - 14,0\%, lokalnie 26,0\% (Wieruszów), 23,0\% (Bełchatów) 20,0\% (Brzeziny); dolnośląskim - 12,5\%, lokalnie 32,0\% (Dzierżoniów), 18,0\% (Ząbkowice Śląskie); małopolskim - 11,5\%, lokalnie 20,0\% (Nowy Sącz), 15,0\% (Dąbrowa Tarnowska).
Mniejsze nasilenie choroby odnotowano na terenie województwa lubuskiego, gdzie porażonych zostało 4,0\% liści oraz mazowieckiego - 3,3\%, lokalnie 22,0\% (Kozienice), 10,0\% (Nowy Dwór Mazowiecki), 8,0\% (Wyszków).

\section{Cebula - Onion}

\section{Mączniak rzekomy cebuli - Peronospora destructor (Berk.) Fr.}

Informacje o występowaniu mączniaka rzekomego cebuli nadesłano w roku 2013 z 9 województw. Stwierdzono mniejszą szkodliwość patogena w porównaniu do obserwacji przeprowadzonych w roku 2012 (7,5\%), odnotowując średnio 6,7\% porażonych roślin. Nadal (od roku 2003) porażenie roślin cebuli kształtuje się poniżej średniej wieloletniej $(13,3 \%)$.

Największe zagrożenie dla plantacji cebuli stanowił patogen w województwie lubelskim, gdzie porażonych zostało średnio 11,3\% roślin, lokalnie 80,0\% (Zamość).

Ponadto większe zagrożenie dla plantacji cebuli obserwowano w województwach: dolnośląskim, gdzie średnio odnotowano $11,0 \%$ porażonych roślin, lokalnie $16,0 \%$ (Dzierżoniów); świętokrzyskim - 11,0\%, lokalnie 25,0\% (Pińczów); kujawsko-pomorskim - 10,0\%, lokalnie 24,0\% (Rypin); lubuskim - 8,0\%, lokalnie $11,0 \%$ (Nowa Sól); wielkopolskim - 7,5\%, lokalnie 20,0\% (Nowy Tomyśl), $10,0 \%$ (Wolsztyn); łódzkim - 3,7\%, lokalnie 18,0\% (Łęczyca); mazowieckim - 3,2\%, lokalnie 15,0\% (Białobrzegi), 5,0\% (Grodzisk Mazowiecki); małopolskim - 1,0\%, lokalnie 5,0\% (Dąbrowa Tarnowska).

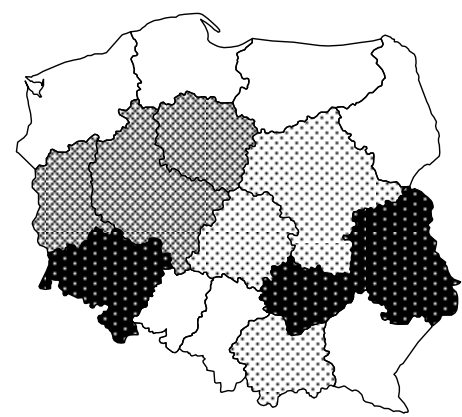

Rys. 28. Maczniak rzekomy cebuli P. destructor (Berk.) Fr.

$\%$ porażonych roślin cebuli $\%$ infected onion plants

\begin{tabular}{ll}
\hline & Brak danych - Data not available \\
& \\
& \\
$7,0-7,0$ & \\
$10,1-10,0$ &
\end{tabular}

\section{Kapusta - Cabbage}

\section{Bielinek kapustnik - Pieris brassicae L.}

Informacje o szkodliwości bielinka kapustnika w 2013 roku nadesłano z 6 województw, a średnio uszkodzonych 
zostało 3,1\% roślin kapustnych. W porównaniu do szkodliwości bielinka kapustnika ocenianej w roku 2012 procent uszkodzonych roślin zmniejszył się o $0,5 \%$, a ponadto nadal (od roku 2000) kształtuje się poniżej wartości średniej wieloletniej wynoszącej 10,8\%.

Większe zagrożenie stanowił szkodnik w województwach: kujawsko-pomorskim, gdzie uszkodził średnio 6,0\% roślin kapustnych (lokalnie Tuchola - 14,0\%); podkarpackim - 4,0\% (lokalnie Leżajsk - 8,0\%); mazowieckim 3,6\% (lokalnie Płońsk - 11,0\%, Piaseczno - 10,0\%, Kozienice $-7,0 \%$, Grodzisk Mazowiecki i Lipsko - 5,0\%).

W pozostałych województwach, $\mathrm{z}$ których zostały nadesłane informacje o występowaniu tego szkodnika, procent uszkodzonych roślin był mniejszy niż średnia, która wynosi $3,1 \%$. Były to województwa: łódzkie - 3,0\% (lokalnie Wieruszów - 6,0\%); małopolskie - 2,8\% (lokalnie Kraków - 10,0\%, Miechów - 5,0\%) i lubuskie - 2,0\%.

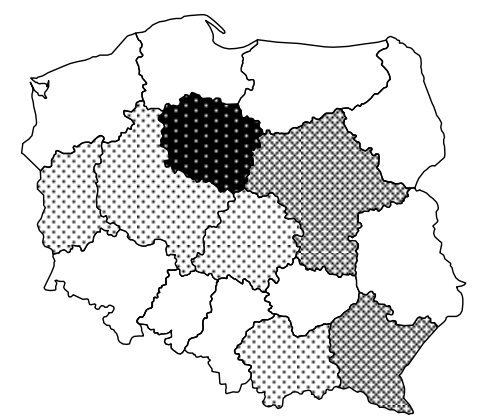

Rys. 29. Bielinek kapustnik P. brassicae $\mathrm{L}$.

$\%$ uszkodzonych roślin kapustnych $\%$ damaged Brassica plants

\begin{tabular}{|l}
\hline \\
\hline \\
$2,0-3,0$ \\
$3,1-4,0$ \\
6,0
\end{tabular}

Piętnówka kapustnica - Mamestra brassicae L.

W roku 2013 szkodliwość piętnówki kapustnicy Oceniana była na terenie 7 województw, ale liczebność szkodnika była mała i spowodował on, że średnio uszkodzonych zostało $-2,8 \%$ roślin kapustnych. Dla porównania średnia wieloletnia wynosi - 8,6\% uszkodzonych roślin.

Najwięcej uszkodzonych roślin przez piętnówkę kapustnicę odnotowano średnio w województwach: lubuskim - 6,0\%; mazowieckim - 5,6\% (lokalnie Warszawa $20,0 \%$, Płońsk - 12,0\%, Piaseczno - 10,0\%, Kozienice 6,0\%); dolnośląskim - 4,0\% (lokalnie Głogów - 7,0\%, Kłodzko - 3,0\%); małopolskim - 2,8\% (lokalnie Nowy Sącz-10,0\%, Miechów - 4,0\%).

Najmniejsze zagrożenie szkodnik stanowił w województwach: kujawsko-pomorskim, gdzie średnio uszkodził 2,5\% roślin kapustnych (lokalnie Tuchola - 7,0\%); łódzkim 2,0\% i podkarpackim - 2,0\% (lokalnie Leżajsk - 4,0\%).

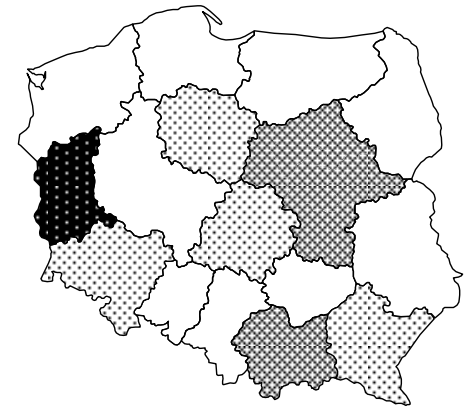

Rys. 30. Piętnówka kapustnica M. brassicae L.

$\%$ uszkodzonych roslin kapustnych $\%$ damaged Brassica plants

$\square$ Brak danych - Data not available

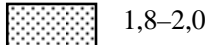

原丽 $2,1-5,6$

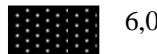

\section{Mszyca kapuściana - Brevicoryne brassicae L.}

Informacje, dotyczące nasilenia występowania mszycy kapuścianej w 2013 roku przekazano z 7 województw. Średnio odnotowano $6,2 \%$ zasiedlonych roślin i było to więcej, w porównaniu z rokiem 2012 o $0,1 \%$, natomiast znacznie mniej w porównaniu ze średnią wieloletnią, tj. o 5,7\%.

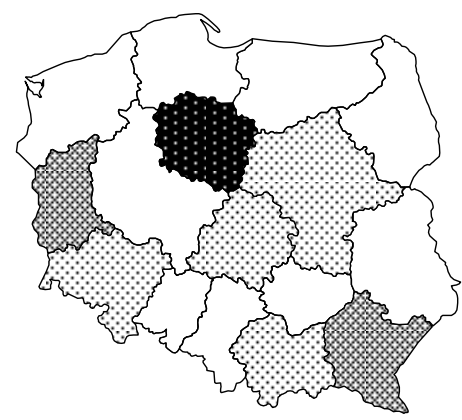

Rys. 31. Mszyca kapuściana B. brassicae L.

$\%$ opanowanych roślin kapustnych $\%$ damaged Brassica plants

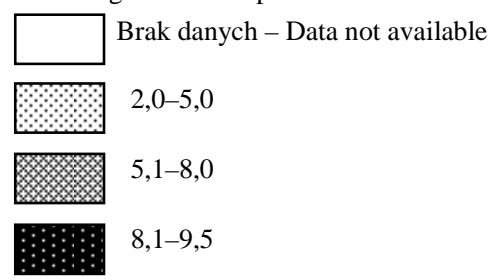

Największe nasilenie występowania mszycy kapuścianej zaobserwowano w województwach: kujawsko-pomorskim, gdzie stwierdzono średnio 9,5\% zasiedlonych roślin kapustnych oraz lubuskim i podkarpackim $-8,0 \%$. 
Największe skupiska mszyc rejestrowano lokalnie w oddziałach terenowych, takich jak: Tuchola $-21 \%$ (województwo kujawsko-pomorskie) oraz Kozienice - 17\% (województwo mazowieckie).

Na podstawie odłowów aspiratorem Johnsona w trzech miejscowościach na terenie Polski początek migracji mszycy kapuścianej stwierdzono: w Winnej Górze - 31 maja, Sośnicowicach - 15 czerwca i Białymstoku - 17 czerwca.

Najliczniejsza migracja tego szkodnika miała miejsce w okolicach Winnej Góry w okresie wiosny i lata i wyniosła $1,1 \%$ ogółu odłowionych aspiratorem mszyc. Jest to wartość identyczna, jak w 2012 roku.

\section{Marchew - Carrot}

\section{Połyśnica marchwianka - Chamaepsila rosae Fabr.}

W roku 2013 nieznacznie zwiększyła się liczebność szkodnika w uprawach marchwi. Średni procent uszkodzonych korzeni wyniósł w skali kraju 4,9 i był o $2,7 \%$ większy w porównaniu do roku 2012. Wartość ta jest wyższa od średniej wieloletniej, która wynosi 4,7\%.

Liczniejsze uszkodzenia korzeni spowodowane żerowaniem larw połyśnicy marchwianki rejestrowano na terenie województw: łódzkiego - średnio 28,4\% (lokalnie Sieradz - 100,0\%); lubelskiego - 6,0\% (lokalnie Lublin $12,0 \%)$.

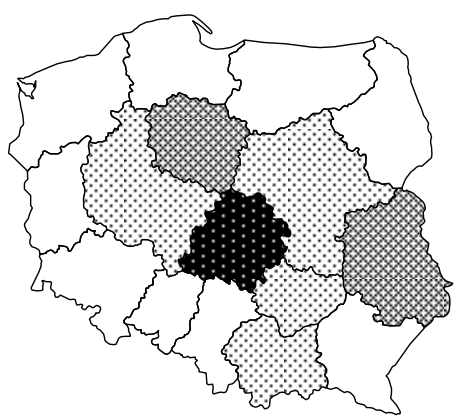

Rys. 32. Połyśnica marchwianka Ch. rosae Fabr.

$\%$ uszkodzonych korzeni marchwi $\%$ damaged roots of carrot

\begin{tabular}{|l}
\hline \\
\hline \\
$0,0-2,0$ \\
$2,1-6,0$ \\
28,4
\end{tabular}

Mniejszą liczbę uszkodzonych korzeni odnotowano w województwach: kujawsko-pomorskim - średnio 4,0\% (lokalnie Torun - 16,0\%); małopolskim i świętokrzyskim 2,0\%; mazowieckim - 1,5\% (lokalnie Grodzisk Mazowiecki $-4,0 \%)$. W województwie wielkopolskim nie odnotowano uszkodzeń spowodowanych przez larwy połyśnicy marchwianki.

\section{Choroby i szkodniki roślin sadowniczych Diseases and pests of orchard plants}

\section{Jabłoń - Apple-tree}

\section{Parch jabłoni - Venturia inaequalis (Cooke) Aderh.}

W roku 2013 nastąpiło zmniejszenie nasilenia występowania parcha jabłoni w porównaniu do wyników obserwacji przeprowadzonych w roku 2012. Średnio w skali kraju stwierdzono 8,5\% porażonych liści (w roku 2012 $9,2 \%$ ) i 5,4\% porażonych owoców (w roku $2012-6,1 \%$ ). Nasilenie występowania parcha jabłoni na liściach i owocach, w odniesieniu do kilkunastu ostatnich lat, maleje. Średnia wieloletnia dla porażenia liści to $20,5 \%$, a dla owoców $12,3 \%$.

Najwięcej porażonych liści przez parch jabłoni stwierdzono średnio w województwach: lubuskim - 18,0\% (lokalnie w oddziale terenowym Świebodzin - 27,0\%); kujawsko-pomorskim - 14,0\% (lokalnie Świecie - 77,0\%, Brodnica - 60,0\%, Chełmno - 15,0\%); świętokrzyskim 12,7\% (lokalnie Końskie - 30,0\% i Pińczów - 20,0\%); łódzkim - 11,0\% (lokalnie Łódź - 35,0\% i Tomaszów Mazowiecki - 15,0\%); podkarpackim - 9,1\%.

Większą szkodliwość obserwowano na terenach takich województw, jak: lubelskie, gdzie stwierdzono średnio $7,9 \%$ porażonych liści; wielkopolskim - 6,3\%; małopolskim - średnio $6,0 \%$, lokalnie w oddziale terenowym Tarnów $-25,0 \%$ i Bochnia - 20,0\%.

Średnio najmniej porażonych liści jabłoni stwierdzono w województwach: podlaskim - 5,3\% (lokalnie oddział terenowy Hajnówka - 19,0\%); śląskim - 5,3\% i dolnośląskim $-4,5 \%$.

Najmniejsze porażenie liści przez parch jabłoni stwierdzono w województwie mazowieckim - 2,3\%.

Natomiast rejony, w których porażenie owoców spowodowane przez parch jabłoni było średnio największe to tereny województw: dolnośląskiego - 17,0\% (lokalnie w oddziałach terenowych: Wrocław $-47,0 \%$, Środa Śląska - 30,0\%); lubelskiego - 6,7\%; mazowieckiego - 5,6\% (lokalnie Ostrów Mazowiecki - 18,0\%).

Ponadto znaczne szkody spowodował parch jabłoni w województwach: wielkopolskim, gdzie odnotowano średnio 5,2\% porażonych owoców; łódzkim - 5,2\% (lokalnie Bełchatów - 25,0\%, Łódź - 15,0\%); śląskim 4,7\%; podkarpackim - 4,7\% (lokalnie Jasło - 8,0\%) i kujawsko-pomorskim - 4,3\% (lokalnie Tuchola - 22,0\%, Świecie - 18,0\%, Toruń - 10,0\%).

Najmniejsze nasilenie choroby odnotowano w województwach: świętokrzyskim, gdzie średnio porażonych zostało 3,6\% owoców (lokalnie w oddziale terenowym Końskie - 12,0\%), podlaskim - 3,5\% (delegatura Białystok - średnio 5,0\%, lokalnie Hajnówka - 12,0\%), małopolskim - 3,3\% (lokalnie Tarnów - 20,0\%, Kraków $15,0 \%)$ i pomorskim $-1,0 \%$. 


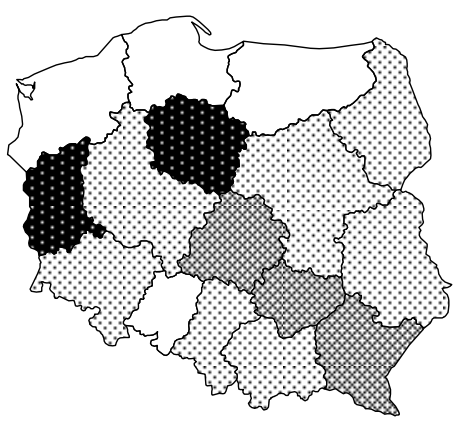

Rys. 33. Parch jabłoni V. inaequalis (Cooke) Aderh.

$\%$ porażonych liści jabłoni

$\%$ infected leaves of apple tree
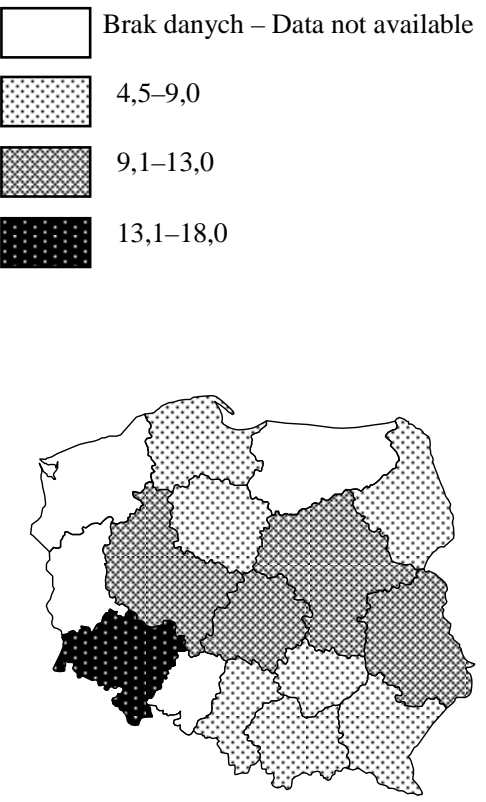

Rys. 34. Parch jabłoni V. inaequalis (Cooke) Aderh. $\%$ porażonych owoców jabłoni $\%$ infected fruits of apple tree

Brak danych - Data not available

$1,0-5,0$

$5,1-6,8$

:

17,0

\section{Kwieciak jabłkowiec - Anthonomus pomorum L.}

W roku 2013 dane o szkodliwości kwieciaka jabłkowca napłynęły tylko z pięciu województw. Średni procent uszkodzonych pąków kwiatowych był o połowę niższy niż w roku ubiegłym i wyniósł 3,1\% (rok 2012 - 6,2\%). Średnia z wielolecia wyniosła $6,7 \%$.

Najwięcej uszkodzonych pąków kwiatowych stwierdzono średnio w województwie lubelskim - 9,7\% (lokalnie Łęczna - 30,0\%).

Znacznie mniejsze szkody spowodował kwieciak jabłkowiec w województwach: lubuskim, gdzie średnio odno- towano $-2,0 \%$ uszkodzonych pąków kwiatowych (lokalnie w oddziale terenowym Żagań - 6,0\%); świętokrzyskim - średnio 2,0\% (lokalnie Końskie - 7,0\%); mazowieckim $1,7 \%$ (lokalnie Pułtusk - 8,0\%, Kozienice - 10,0\%).

W województwie śląskim nie stwierdzono żadnych szkód powodowanych przez tego szkodnika.

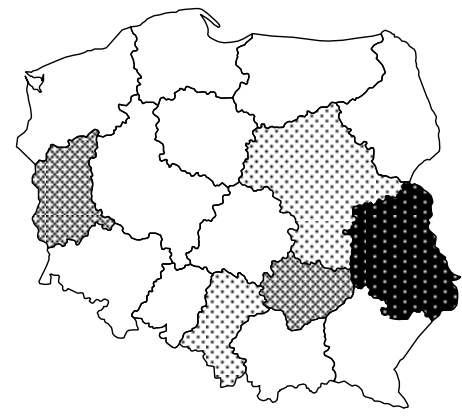

Rys. 35. Kwieciak jabłkowiec A. pomorum $\mathrm{L}$.

\% uszkodzonych pąków kwiatowych jabłoni $\%$ damaged flover buds of apple tree

$\square$ Brak danych - Data not available
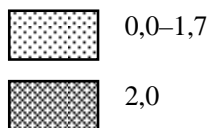

9,7 9,7

\section{Owocnica jabłkowa - Hoplocampa testudinea Klug.}

Średnia w skali kraju szkodliwość owocnicy jabłkowej w roku 2013 była na niemal takim samym poziomie, jak w roku ubiegłym i wynosiła 2,6\% (rok 2012 - 2,7\%) uszkodzonych zawiązków i kształtowała się poniżej poziomu średniej z wielolecia, wynoszącej 3,5\%.

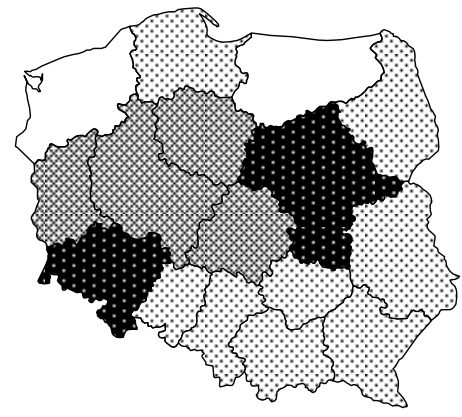

Rys. 36. Owocnica jabłkowa H. testudinea Klug. $\%$ uszkodzonych zawiązków jabłoni $\%$ damaged fruit buds of apple tree

$\square$ Brak danych - Data not available

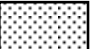
$0,0-3,0$

济 $3,1-4,4$ 
Średnio najwięcej uszkodzonych zawiązków jabłoni stwierdzono w województwach: dolnośląskim - 6,3\% (lokalnie w oddziale terenowym Wrocław $-25,0 \%$, Środa Śląska - 15,0\%); mazowieckim - 4,5\% (lokalnie Lipsko 60,0\%); kujawsko-pomorskim - 4,1\% (lokalnie Tuchola 18,0\%, Chełmno - 12,0\%); łódzkim - 3,8\% (lokalnie Bełchatów - 13,0\%); lubuskim - 3,7\% (lokalnie Żagań $7,0 \%$ ); wielkopolskim $-3,2 \%$ oraz lubelskim $-3,0 \%$.

Najmniej szkód odnotowano w województwach: podkarpackim - 2,1\% uszkodzonych zawiązków; świętokrzyskim - 2,0\%; małopolskim - 1,3\% i podlaskim - 1,0\% .

W województwie pomorskim i opolskim nie stwierdzono żadnych szkód powodowanych przez tego szkodnika.

\section{Owocówka jabłkóweczka - Cydia pomonella L.}

Średnie w skali kraju szkody, spowodowane przez owocówkę jabłkóweczkę w roku 2013 wynosiły 3,4\% uszkodzonych owoców jabłoni (w roku 2012 - 3,7\%). Średnia wieloletnia szkodliwość ukształtowała się na poziomie 5,3\% uszkodzonych owoców.

Najwięcej uszkodzonych owoców stwierdzono średnio w województwach: dolnośląskim - 10,0\% (lokalnie w oddziale terenowym Środa Śląska - 40,0\%, Wrocław 22,0\%,); śląskim - 8,5\% (lokalnie Cieszyn - 20,0\%); lubelskim - 4,6\%; łódzkim - 3,5\% (lokalnie Łask - 9,0\%) i kujawsko-pomorskim - 3,4\% (lokalnie Tuchola $17,0 \%)$.

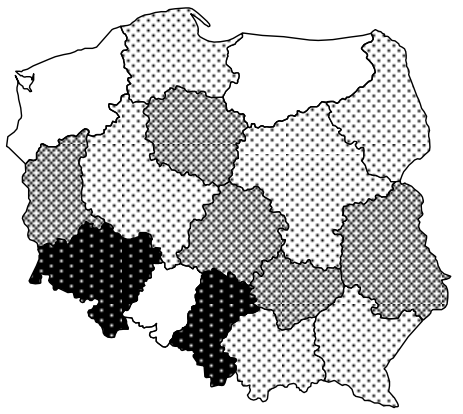

Rys. 37. Owocówka jabłkóweczka C. pomonella $\mathrm{L}$.

$\%$ uszkodzonych owoców jabłoni $\%$ damaged fruits of apple tree

\begin{tabular}{|c|c|}
\hline & Brak danych - Data not available \\
\hline - & $1,0-2,0$ \\
\hline 息 & $2,1-8,0$ \\
\hline & $8,1-10,0$ \\
\hline
\end{tabular}

Najmniej szkód, średnio poniżej 3,4\% uszkodzonych owoców, wyrządziła owocówka jabłkóweczka w województwach: świętokrzyskim - 2,8\%; lubuskim - 2,5\%; podkarpackim - 2,0\% (lokalnie oddział terenowy Ropczyce - 10,0\%); podlaskim - 2,0\% (lokalnie Hajnówka $6,0 \%$ ); małopolskim - 1,5\%; wielkopolskim - 1,4\%; mazowieckim i pomorskim - 1,0\%.

\section{Śliwa-PIum-tree}

Brunatna zgnilizna drzew pestkowych - Monilinia laxa (Aderh. et Ruhl.) Honey

Od 2008 roku rozpoczęto gromadzenie informacji na temat szkodliwości brunatnej zgnilizny drzew pestkowych na pędach śliw. W roku 2013 informacje o występowaniu choroby nadesłano z terenu 4 województw. Stwierdzono zwiększenie nasilenia występowania choroby, porażenie pędów wyniosło średnio 3,0\% (w roku $2012-1,7 \%$ ), co kształtowało się poniżej poziomu średniej $\mathrm{z}$ wielolecia $(3,6 \%)$.

Większe zagrożenie ze strony patogena odnotowano w województwie mazowieckim, gdzie stwierdzono średnio $5,2 \%$ porażonych pędów (lokalnie w oddziale terenowym Płońsk - 12,0\%); kujawsko-pomorskim - średnio 3,7\% (lokalnie Lipno - 15,0\%, Włocławek - 10,0\%, Tuchola $6,0 \%)$.

Najmniejszą szkodliwość brunatnej zgnilizny drzew pestkowych na śliwach stwierdzono w województwie lubelskim - średnio 2,0\% porażonych pędów (lokalnie Kraśnik - 8,0\%) i wielkopolskim - średnio 1,0\%.

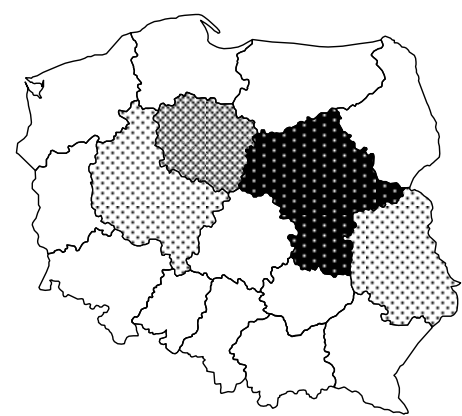

Rys. 38. Brunatna zgnilizna drzew pestkowych - M. laxa (Aderh. et Ruhl.) Honey

$\%$ porażonych pędów śliw

$\%$ infected shoots of plum tree

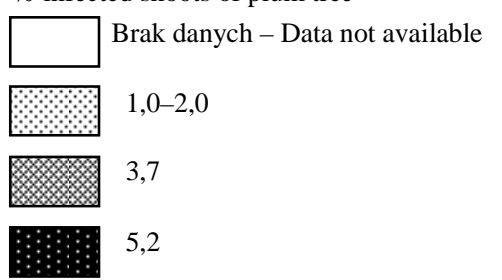

\section{Owocnice śliwowe - Hoplocampa spp.}

W roku 2013 informacje o uszkodzeniu zawiązków śliw przez owocnice śliwowe nadesłano z 11 województw. W porównaniu z oceną przeprowadzoną w roku 2012 stwierdzono nieznaczne zwiększenie szkodliwości. Średnio odnotowano 3,9\% uszkodzonych zawiązków śliw (w roku 2012 - 3,7\%). Średnia wieloletnia kształtuje się na poziomie 8,5\% uszkodzonych zawiązków śliw.

Średnio największą liczbę uszkodzonych zawiązków śliw stwierdzono w województwach: mazowieckim $10,0 \%$ (lokalnie $\mathrm{w}$ oddziale terenowym Lipsko - 60,0\%; Płońsk - 12,0\%); wielkopolskim - 6,0\% (lokalnie Konin - 
20,0\%); kujawsko-pomorskim - 5,9\% (lokalnie Chełmno $36,0 \%$, Tuchola - 21,0\%, Toruń - 8,0,\%, Bydgoszcz 8,0\%); łódzkim - 4,7\% (lokalnie Tomaszów Mazowiecki 9,0\%); lubuskim - 4,0\%.

Mniej niż 4,0\% uszkodzonych zawiązków śliw przez owocnice śliwowe odnotowano średnio w województwach: dolnośląskim - 3,9\% (lokalnie oddział terenowy Trzebnica - 8,0\%); świętokrzyskim - 2,3\% (lokalnie Staszów 8,0\%); małopolskim - 2,0\% (lokalnie Tarnów - 25,0\%); śląskim i podkarpackim -2,0\% oraz lubelskim - 1,0\%.

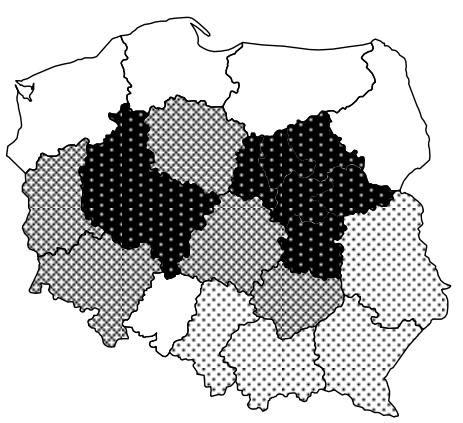

Rys. 39. Owocnice śliwowe Hoplocampa spp.

$\%$ uszkodzonych zawiązków śliw $\%$ damaged fruit buds of plum tree

\begin{tabular}{ll}
\hline & Brak danych - Data not available \\
\hline 1, & \\
$1,0-2,0$ \\
$2,1-5,9$ \\
$6,0-10,0$
\end{tabular}

\section{Owocówka śliwkóweczka - Cydia funebrana Tr.}

Średnia w skali kraju szkodliwość owocówki śliwkóweczki w roku 2013 zwiększyła się w porównaniu do odnotowanej w roku 2012 i wynosiła 4,3\% uszkodzonych owoców śliw (w roku 2012 - 3,5\%). Średnia wieloletnia szkodliwość ukształtowała się na poziomie 7,8\% uszkodzonych owoców.

Szkodnik najliczniej wystąpił w województwach: świętokrzyskim, gdzie średnio spowodował uszkodzenia $10,3 \%$ owoców śliw (lokalnie w oddziale terenowym Staszów - 55,0\%, Busko Zdrój - 15,0\%); śląskim - 7,0\% (lokalnie Częstochowa - 30,0\%); kujawsko-pomorskim $5,6 \%$ (lokalnie Chełmno - 30,0\%, Tuchola - 22,0\%, Toruń $-12,0 \%)$; lubuskim $-5,0 \%$.

Do województw, w których znaczenie gospodarcze owocówki śliwkóweczki było najmniejsze należały: mazowieckie, gdzie średnio zostało uszkodzonych - 4,2\% owoców (lokalnie Płońsk - 12,0\%); dolnośląskie - 3,0\% (lokalnie Trzebnica - 6,0\%); łódzkie - 3,0\% (lokalnie Poddębice $-7,0 \%$ ); małopolskie - 3,0\% (lokalnie Tarnów $-4,0 \%$ ); wielkopolskie - 3,0\% (lokalnie Turek i Konin $7,0 \%$ ); lubelskie - 2,5\% (lokalnie Kraśnik - 5,0\%); podkarpackie $-1,0 \%$.

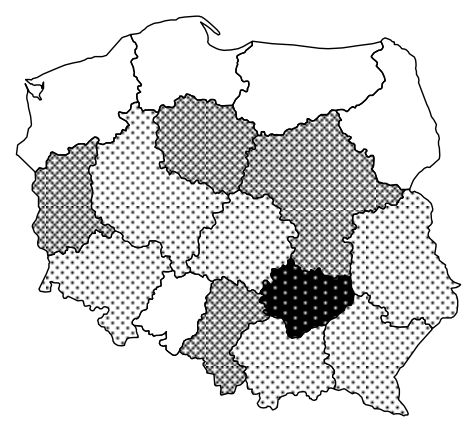

Rys. 40. Owocówka śliwkóweczka C. funebrana $\mathrm{Tr}$.

$\%$ uszkodzonych owoców śliw $\%$ damaged fruits of plum tree

$\square$ Brak danych - Data not available

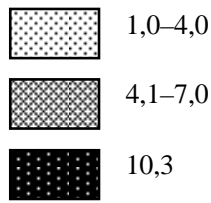

\section{Czereśnia i wiśnia-Cherry-tree}

Brunatna zgnilizna drzew pestkowych - Monilinia laxa (Aderh. et Ruhl.) Honey

Informacje o porażeniu pędów czereśni przez sprawcę brunatnej zgnilizny drzew pestkowych w roku 2013 nadesłano z 8 województw. Średnio na plantacjach czereśni stwierdzono zwiększenie nasilenia choroby w porównaniu do odnotowanego w roku $2012(1,4 \%)$ do 3,4\% porażonych pędów. Średnia z wielolecia wynosi $3,9 \%$ porażonych pędów.

Największe nasilenie choroby stwierdzono w województwach: lubuskim, gdzie średnio odnotowano 8,0\% porażonych pędów czereśni (lokalnie oddział terenowy Nowa Sól - 14,0\%); łódzkim - 7,0\% (lokalnie Skierniewice $-10,0 \%$ ).

Najmniej porażonych pędów czereśni stwierdzono w województwach: wielkopolskim - 3,0\%; kujawskopomorskim - 2,8\% (lokalnie Lipno - 5,0\%); dolnośląskim $-2,0 \%$; świętokrzyskim - 1,0\%; małopolskim - 1,0\%.

W województwie lubelskim nie stwierdzono szkód powodowanych przez tego patogena.

Natomiast stwierdzono zmniejszenie nasilenia występowania choroby na wiśniach. W roku 2013 przekazano informacje z 10 województw i średnio stwierdzono 5,0\% porażonych pędów (w roku $2012-5,7 \%$ ). Średnia z wielolecia wynosi $6,2 \%$.

Najwięcej porażonych pędów wiśni stwierdzono w województwach: łódzkim, gdzie średnio odnotowano 9,5\% (lokalnie Tomaszów Mazowiecki - 15,0\%); wielkopolskim - 9,0\% (lokalnie Chodzież - 20,0\%); Mazowieckim - 6,2\% (lokalnie Lipsko - 30,0\%, Piaseczno 20,0\%); lubuskim - 6,0\% (lokalnie Nowa Sól - 8,0\%); kujawsko-pomorskim - 5,3\% (lokalnie Tuchola - 14,0\%); małopolskim - 5,0\% (lokalnie Limanowa-27,0\%). 
Najmniejsze nasilenie choroby obserwowano w województwach: podkarpackim, gdzie porażonych zostało 3,0\% pędów wiśni; świętokrzyskim - 2,7\% (lokalnie Starachowice $-7,0 \%$ ); dolnośląskim - 2,0\% (lokalnie Wałbrzych - 21,0\%); lubelskim - 1,5\% (lokalnie Puławy $4,0 \%)$.

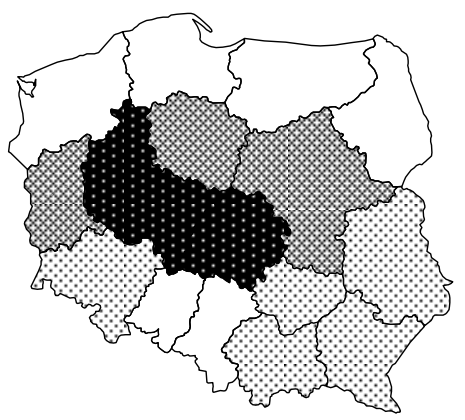

Rys. 41. Brunatna zgnilizna drzew pestkowych - M. laxa (Aderh. et Ruhl.) Honey

$\%$ porażonych pędów wiśni

$\%$ infected shoots of cherry tree
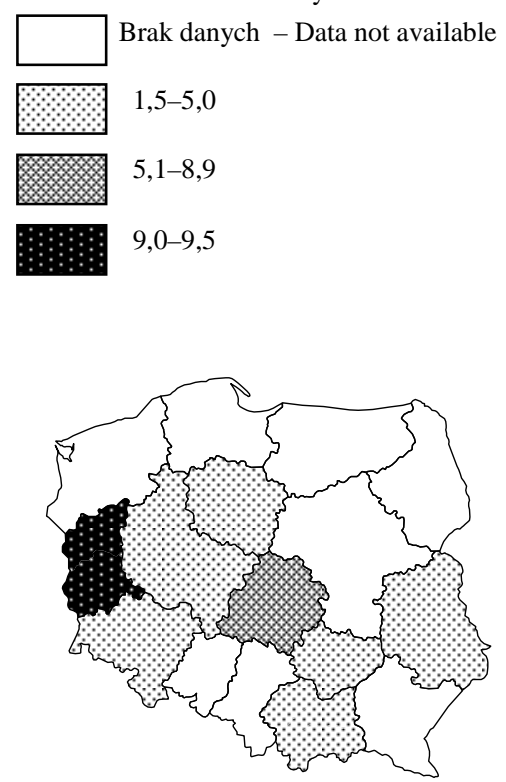

Rys. 42. Brunatna zgnilizna drzew pestkowych - M. laxa (Aderh. et Ruhl.) Honey

$\%$ porażonych pędów czereśni \% infected shoots of cherry tree

\begin{tabular}{|l}
\hline Brak danych - Data not available \\
$0,0-3,0$ \\
7,0 \\
8,0
\end{tabular}

\section{Nasionnica trześniówka - Rhagoletis cerasi L.}

Średnia liczba uszkodzonych przez nasionnicę trześniówkę owoców czereśni i wiśni (na podstawie obserwacji przeprowadzonych w roku 2013 w 10 województwach) zmniejszyła się i wynosiła 1,9\% (2012 - 2,9\%). Średnia $\mathrm{z}$ wielolecia wynosi 3,6\%.

Największe szkody nasionnica trześniówka wyrządziła w województwach: małopolskim, na terenie którego stwierdzono średnio 3,0\% uszkodzonych owoców czereśni i wiśni (lokalnie w oddziale terenowym Tarnów - 15,0\% czereśni); świętokrzyskim - 3,0\% (lokalnie Busko Zdrój $8,0 \%$ czereśni); mazowieckim - 2,5\% (lokalnie Płońsk 13,0\% wiśni); dolnośląskim - 2,0\% (lokalnie Trzebnica $20,0 \%$ czereśni) i wielkopolskim - 2,0\% (lokalnie Kościan $-5,0 \%$ czereśni).

W pozostałych województwach, w których prowadzono ocenę szkodliwości nasionnicy trześniówki, uszkodzenie owoców wynosiło poniżej 2,0\% . Były to: łódzkie 1,4\%; lubelskie - 1,0\% (lokalnie Opole Lubelskie - 5,0\% czereśni); podkarpackie - 1,0\%; kujawsko-pomorskie 0,8\% (lokalnie Chełmno - 8,0\% owoców czereśni).

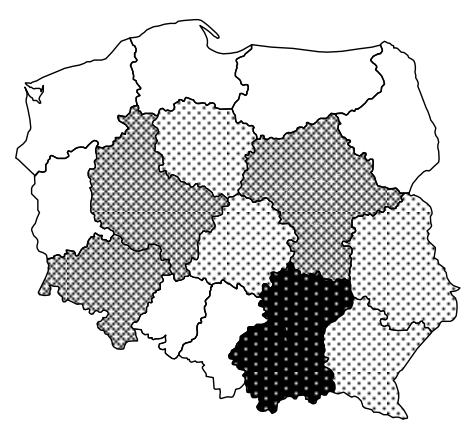

Rys. 43. Nasionnica trześniówka $R$. cerasi L.

$\%$ uszkodzonych owoców wiśni i czereśni $\%$ damaged fruits of sour and sweet cherries

$\square$ Brak danych - Data not available

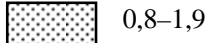

$2,0-2,5$

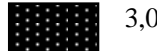

\section{Truskawka - Strawberry}

\section{Szara pleśń truskawki - Botrytinia fuckeliana (De Bary)} Whetzel.

W roku 2013 nastąpiło zwiększenie nasilenia występowania szarej pleśni truskawki w porównaniu do obserwowanego w roku 2012. Średnio w skali kraju porażonych zostało 6,2\% owoców (w 2012 roku - 5,1\%). Średnia z wielolecia wynosi 7,5\% porażonych owoców. Największe średnie porażenie owoców truskawki przez szarą pleśń odnotowano w województwach: łódzkim $16,6 \%$ (lokalnie w oddziałach terenowych: Tomaszów Mazowiecki - 50,0\%, Bełchatów - 40,0\%, Piotrków Trybunalski - 27,0\%); lubuskim - 9,0\% (lokalnie Nowa Sól - 15,0\%); dolnośląskim - 8,9\% (lokalnie: Ząbkowice Śląskie $-65,0 \%$, Świdnica - 36,0\%, Dzierżoniów - 20,0\%, 
Głogów - 16,0\%, Oleśnica - 20,0\%); lubelskim - 7,4\%; mazowieckim $-7,4 \%$.

Poniżej 6,0\% porażonych owoców średnio w województwie stwierdzono w: wielkopolskim - 5,8\%; małopolskim $-5,6 \%$ (lokalnie w oddziałach terenowych: Limanowa - 24,0\%, Tarnów - 20,0\%, Bochnia i Nowy Sącz $15,0 \%$ ); świętokrzyskim - 5,0\% (lokalnie Kielce - 15,0\%); śląskim - 4,5\% (lokalnie Kłobuck - 35,0\%); kujawskopomorskim - 4,0\%; podlaskim - 2,9\% (lokalnie Hajnówka $-11,0 \%)$; podkarpackim $-2,5 \%$; pomorskim - 1,0\%.

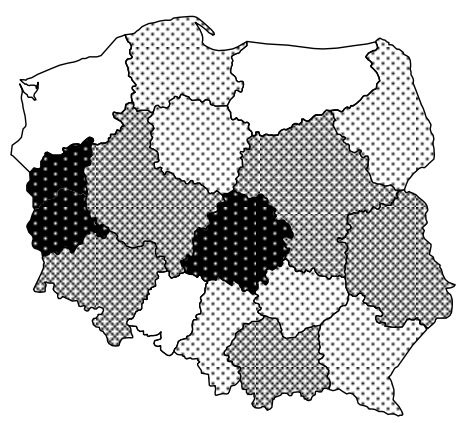

Rys. 44. Szara pleśń truskawki B. fuckeliana (De Bary) Whetzel.

$\%$ porażonych owoców truskawki $\%$ infected fruits of strawberry

\begin{tabular}{ll}
\hline & Brak danych - Data not available \\
& $1,0-5,0$ \\
$5,1-8,9$ &
\end{tabular}

Baza danych, na której opiera się przedstawione opracowanie, jest jedyną w kraju, stąd brak możliwości porównania wyników oceny uszkodzeń powodowanych przez agrofagi na terenie Polski z publikacjami innych autorów. Jedną z przyczyn braku takich pozycji w literaturze jest konieczność zastosowania takich samych metod monitorowania agrofagów, jakie są stosowane w monitorowaniu agrofagów na terenie całego kraju, aby można było porównywać wyniki obserwacji.

\section{Wnioski / Conclusions}

1. Monitorowanie poziomu uszkodzeń powodowanych przez agrofagi roślin uprawnych jest ważnym elementem integrowanej ochrony roślin, tj. wiedzy dotyczącej aktualnej zdrowotności roślin uprawnych w Polsce, a pośrednio także gradacji szkodników. Ponadto wykonywane obserwacje polowe umożliwiają zaobserwowanie przenikania nowych agrofagów rozprzestrzeniających się z terenów innych krajów.

2. W roku 2013, w porównaniu do wyników monitorowania z roku 2012, w skali kraju stwierdzono zwięk- szenie uszkodzeń wyrządzanych na roślinach uprawnych przez następujące agrofagi: $B$. graminis, $P$. recondita f. sp. tritici, Fusarium spp., M. yallundae, G. graminis - na pszenicy, Fusarium spp. - na kukurydzy, L. decemlineata - na ziemniaku, Leptosphaeria spp. - na rzepaku ozimym, $P$. cubensis, $P$. syringae pv. lachrymans, $B$. brassicae, Ch. rosae - na warzywach oraz M. laxa, Hoplocampa spp., C. funebrana, B. fuckeliana - w sadach.

3. W ostatnim 10-leciu obserwowano stopniowe zwiększanie średniej dla Polski szkodliwości w przypadku takich agrofagów, jak: $P$. recondita f. $\mathrm{sp}$. tritici i $H$. equestris - na pszenicy ozimej, C. beticola - na buraku cukrowym, Leptosphaeria spp., C. assimilis i $D$. brassicae - na rzepaku ozimym oraz $P$. syringae pv. lachrymans - na ogórku.

4. W przypadku wielu agrofagów ich średnia w skali kraju szkodliwość w ostatnim 10-leciu plasowała się poniżej średniej z wielolecia (1991-2013) i wykazywała zmniejszanie poziomu, ale $\mathrm{w}$ przypadku niektórych z nich odnotowano zwiększenie szkód przez nie powodowanych i odnosi się to do: $P$. infestans - na ziemniaku, Hoplocampa spp. - na śliwach, M. laxa na wiśni oraz $B$. fuckeliana - na truskawce.

5. Mimo tego, że uszkodzenia wyrządzane przez niektóre agrofagi od roku 2004 średnio w Polsce plasują się poniżej obliczonych wartości średnich wieloletnich (1991-2013), to nadal stanowią duże zagrożenie dla roślin żywicielskich, a dotyczy to:

- B. graminis - który od roku 2004 porażał około 12-22\% źdźbeł pszenicy ozimej (średnia wieloletnia $23,2 \%)$,

- Oulema spp., które od 2004 roku uszkadzały około 6-8\% źdźbeł pszenicy ozimej (średnia wieloletnia $9,0 \%)$,

- P. infestans, która od 2004 roku porażała około 20-40,0\% roślin ziemniaka (średnia wieloletnia $44,0 \%)$,

- M. aeneus, który od roku 2004 uszkadzał około 8-11\% pąków kwiatowych rzepaku ozimego (średnia wieloletnia - 11,2\%),

- V. inaequalis, który od roku 2004 porażał 5-10\% owoców (średnia wieloletnia - 12,3\%).

6. Stwierdzono, że nastąpiło zmniejszenie w skali kraju szkód powodowanych przez agrofagi kukurydzy (Fusarium spp., O. frit, O. puzilla, O. nubilalis), których monitorowanie po wielu latach wznowiono w roku 2006.

Autorzy zwracają uwagę na fakt, że wykonywanie obserwacji przez inspektorów PIORiN na terenie Polski staje obecnie pod znakiem zapytania i jak dotąd nie wiadomo, jaka instytucja przejmie tę działalność lub czy nie zostanie ona zawieszona. Stąd trzeba liczyć się z faktem, że może zabraknąć bardzo ważnego elementu integrowanej ochrony roślin, jakim jest znajomość aktualnego stanu fitosanitarnego roślin uprawnych w Polsce, a pośrednio także informacji dotyczących gradacji szkodników. 


\section{Literatura / References}

Aneksy do Instrukcji dla służby ochrony roślin z zakresu prognoz, sygnalizacji i rejestracji - do Części II, tom I i II (1993) „Metody sygnalizacji i prognozowania pojawu chorób i szkodników roślin oraz do Części III (1976) „Rejestracja ogólna i szczegółowa chorób i szkodników roślin uprawnych”. 1998. Wyd. I. Inst. Ochr. Roślin, Poznań, 47 ss.

Instrukcja dla służby ochrony roślin z zakresu prognoz, sygnalizacji i rejestracji. Część III. Rejestracja ogólna i szczegółowa chorób i szkodników roślin uprawnych. 1976. Wyd. IV. Inst. Ochr. Roślin, Poznań, 162 ss.

Instrukcja dla służby ochrony roślin z zakresu prognoz, sygnalizacji i rejestracji. Część I. Ogólna. 1982. Wyd. V. Inst. Ochr. Roślin, Poznań, 165 ss.

Instrukcja dla służby ochrony roślin z zakresu prognoz, sygnalizacji i rejestracji. Część II t. I i II. Metody sygnalizacji i prognozowania pojawu chorób i szkodników roślin. 1993. Wyd. IV. Inst. Ochr. Roślin, Poznań, t. I, 200 ss, t. II, 200 ss.

Walczak F. (red.). 2007. Poradnik sygnalizatora ochrony zbóż. Inst. Ochr. Roślin - PIB, Poznań, 111 ss.

Walczak F. (red.). 2008. Poradnik sygnalizatora ochrony rzepaku. Inst. Ochr. Roślin - PIB, Poznań, 153 ss.

Walczak F., Bandyk A., Jakubowska M., Roik K., Tratwal A., Złotkowski J. 2013. Stan fitosanitarny roślin uprawnych w Polsce w roku 2012 i spodziewane wystąpienie agrofagów w 2013. Inst. Ochr. Roślin - PIB, Poznań, 122 ss.

Walczak F., Bandyk A., Jakubowska M., Roik K., Tratwal A., Złotkowski J. 2014. Stan fitosanitarny roślin uprawnych w Polsce w roku 2013 i spodziewane wystąpienie agrofagów w 2014. Inst. Ochr. Roślin - PIB Poznań, 120 ss. 